\title{
Colonialism and Development: A Comparative Analysis of Spanish and British Colonies $^{1}$
}

\author{
Matthew Lange \\ McGill University \\ James Mahoney \\ Northwestern University \\ Matthias vom Hau \\ Brown University
}

\begin{abstract}
Recent research shows that colonialism reversed levels of development in much of the non-European world. To explain this reversal, analysts focus on conditions within the colonized areas. By contrast, drawing on evidence from Spanish and British colonialism, the authors show that the economic models of the colonizing nations also affected the reversals of fortune. Mercantilist Spain tended to colonize most extensively precolonial regions that were populous and highly developed; in turn, extensive Spanish colonization had negative consequences for postcolonial development. In comparison, liberal Britain tended to colonize most extensively precolonial regions that were sparsely populated and underdeveloped; in turn, extensive British colonialism had comparatively positive effects. Thus, both Spain and Britain reversed the fortunes of precolonial regions, but in largely opposite ways.
\end{abstract}

Recent research argues that European colonialism caused a great reversal in levels of development throughout much of the non-European world (Acemoglu, Johnson, and Robinson 2001, 2002; Engerman and Sokoloff

${ }^{1}$ All three authors contributed equally to this article. For helpful comments and advice (not all of it heeded), we thank Jennifer Darrah, Marion Fourcade-Gourinchas, Jeffrey Herbst, Mara Loveman, James Robinson, Dietrich Rueschemeyer, Charles Tilly, Celso Villegas, and the $A J S$ reviewers. James Mahoney's work on this project is supported by the National Science Foundation (grant 0093754). Direct correspondence to James Mahoney, Scott Hall, 601 University Place, Northwestern University, Evanston, Illinois 60208. E-mail: James-Mahoney@northwestern.edu

(C) 2006 by The University of Chicago. All rights reserved. 0002-9602/2006/11105-0004\$10.00

1412 AJS Volume 111 Number 5 (March 2006): 1412-62 
2002). Those territories that were the most economically prosperous before colonialism often became the least economically developed after colonialism. Likewise, the poorest precolonial regions often emerged as the wealthiest in the postcolonial era.

To this point, researchers have accounted for the reversal in terms of conditions within the colonized areas. As potential explanations, they emphasize the factor endowments (broadly conceived) present at the time of colonialism and the types of institutions that these endowments encouraged European colonists to establish. For example, Engerman and Sokoloff (2002) argue that the kinds of soil, climate, and demography that were associated with precolonial wealth often led colonists to establish extractive institutions. In turn, these extractive institutions produced unequal societies, which had negative effects on future development. By contrast, precolonial areas with different kinds of factor endowments were often spared the worst inequality-enhancing effects of colonialism and could prosper in the postcolonial period. Similarly, Acemoglu et al. (2001, 2002) argue that population density and disease environment greatly affected colonial trajectories. They contend that Europeans preferred to settle sparsely populated areas with favorable disease climates (which tended to be poor) and were more likely to establish productive institutions (i.e., property rights) in these colonies than in wealthier areas marked by denser populations and less favorable disease climates.

Such an exclusive focus on domestic conditions within colonies ignores other factors that shaped colonial and postcolonial trajectories. Because colonialism invariably consists of two-way relations between colonizer and colonized (Robinson 1972; Stoler and Cooper 1997), the characteristics of the former as well as those of the latter are relevant for understanding the effect of colonialism on development. Indeed, a rich literature is concerned with differences in the orientation of the European colonial powers and finds that the identity of the colonizing nation explains variation in postcolonial development. For example, quantitative studies have found that the identity of the colonizer affects contemporary growth rates (Alam 1994; Grier 1999; Bertocchi and Canova 2002) and democratic survival (Bernhard, Reenock, and Nordstrom 2004). Likewise, many excellent comparative-historical studies have argued that contrasts in the orientation of different colonizers shape the socioeconomic and cultural institutions of postcolonial societies (e.g., Fieldhouse 1966; Landes 1998; Lang 1975; Miles 1994; Pagden 1995; Young 1994). In this study, we bring the characteristics of colonizing powers back into the picture by arguing that differences in the economic models of Britain and Spain had large consequences for the kinds of areas they preferred to settle, the extent of colonial institutional building they pursued, and, ultimately, the developmental legacies they left behind. 
American Journal of Sociology

Our core argument focuses on the causes and consequences of different levels of colonialism for Spanish and British colonies. We define level of colonialism as the extent to which a colonizing power installs economic, political, and sociocultural institutions in a colonized territory. To estimate this level across different colonial territories, we draw on a large range of secondary sources and our own previous research on Spanish and British colonialism. In pursuing this approach, we follow recent methodological writings that suggest that qualitative approaches to measurement based on expert knowledge may achieve higher levels of validity than quantitative approaches that rely on "objective" indicators (Adcock and Collier 2001; Bowman, Lehoucq, and Mahoney 2005; Ragin 2000). At the same time, however, we cross-check our findings using statistical proxies for key variables when appropriate.

The argument proceeds in two parts. In the first part, we show that similar kinds of factor endowments led Spanish and British colonizers to pursue different levels of colonial institutional establishment. The Spanish generally settled and concentrated colonial institutions in those areas that were the most populous and most politically and economically developed at the beginning of the colonial epoch. In contrast, the British pursued comparatively limited settlement and institutional transformation in the more populous and more politically and economically developed precolonial areas. Hence, precolonial level of development is positively associated with level of Spanish colonialism, but negatively associated with level of British colonialism. This finding contradicts recent work on the great reversal that assumes that factor endowments have similar consequences for institution building across all European colonizers.

In the second part of our argument, we show that level of colonialism had opposite effects on long-run socioeconomic development for the Spanish and British colonies. More extensive Spanish colonialism produced predatory states and dysfunctional markets, and it also left behind highly stratified societies. Less extensive Spanish colonialism did not directly lead to the creation of effective states and markets, but it did spare regions from the establishment of the most destructive institutions, giving them a chance to experience development in the aftermath of the colonial period. Conversely, more extensive British colonialism introduced a rule of law, effective administration, and competitive markets, promoting development in the postcolonial period. Yet limited forms of British colonialism distorted existing institutions in ways that greatly hindered future development. Hence, the effect of level of colonialism on development is the opposite for Spanish and British colonialism.

This analysis is part of the ongoing scholarly quest to understand the ways in which colonial institutions shape long-run human well-being. Much of this literature is animated by the question of whether colonialism 
in general has positive or negative consequences for development (e.g., Frank 1972; Kohli 2004; Mamdani 1996; Rodney 1982; Young 1994). By contrast, our approach is to ask about the consequences of given levels of colonialism for regions that experienced colonial domination. This focus does not allow us to evaluate what might have happened if a particular territory had not been colonized at all. Nor can we directly address the question of whether, for example, the British left behind better institutions than the Spanish (see La Porta et al. 1998, 1999; Landes 1998). However, our approach does estimate for the first time the effects of experiencing more colonialism or less colonialism across territories colonized by different European powers.

The study builds in part on the recent work of economists, but it brings to the discussion a more sociological approach. We follow the economics literature in examining the extent to which colonialism established property rights (North and Thomas 1973; North 1990). However, we view "property rights" in terms of state legal institutions, in particular, the organization of courts and police, or what Weber (1978) referred to as "legal orders." We thus focus on the extent to which colonialism left behind an effective rule of law, including through the creation of legal institutions that were not directly linked to expected returns in the market (see Lange 2005; Mendez, O'Donnell, and Pinheiro 1999). Furthermore, we view states as administrative apparatuses, and thus we consider the ways in which colonialism shaped the capacities of state actors to promote developmental projects (e.g., Rueschemeyer and Evans 1985; Migdal 1988). Finally, we call attention to a broader array of institutions than simply those related to law, order, and administration. In particular, we focus on colonial institutions that shaped patterns of ethnoracial stratification, arguing that these institutions are especially important for explaining longrun social development, which we contend has partially separate determinants from economic development.

We examine 39 countries that were formerly British colonies and 18 former Spanish colonies. ${ }^{2}$ This population encompasses the vast majority of the Spanish and British colonies. ${ }^{3}$ The approximate timing of coloni-

\footnotetext{
${ }^{2}$ As our choice of terms indicates, we focus on British overseas colonialism. The analysis does not consider cases such as Ireland and Wales which some researchers view as representing instances of "internal colonialism" (e.g., Hechter 1975). Likewise, with Spain (i.e., the allied kingdoms of Castile and Aragon), we focus on its overseas empire rather than its territorial possessions in Europe.

${ }^{3}$ For Spanish colonialism, we focus on the colonies in the Americas. Thus, we do not include the Philippines, the Canary Islands, Equatorial Guinea, and Spanish Morocco. For British colonialism, we do not examine the "mandate colonies" of Iraq, Israel/ Palestine, and Jordan. These territories were only briefly held by the British during the interwar period. We also exclude small island states such as Malta, St. Lucia, and
} 


\section{American Journal of Sociology}

alism in these countries is provided in table 1. To explore hypotheses, we rely extensively on qualitative, historical information from the work of area specialists and country experts. We use this information both to establish simple correlations between variables and to explore the mechanisms connecting variables with one another. This latter mode of analysis is especially important because it enables us to assert with some confidence that cross-case correlations reflect causation even in the absence of a multivariate statistical framework.

\section{A THEORY OF COLONIALISM}

Our analysis of the causes and effects of levels of Spanish and British colonialism is built around a more general theoretical framework. This framework distinguishes two ideal-typical economic models that can characterize colonizing powers: mercantilist and liberal. A mercantilist model organizes productive activity to obtain national economic self-sufficiency and short-term gains through favorable trade balances and the accumulation of precious metals (Heckscher 1935). Under this model, political authorities use the state to establish trade restrictions and support extramarket institutions that provide rents to certain groups and deny privileges to others (Ekelund and Tollison 1981). As such, mercantilism aligns economic and state elites, concentrating resources in few hands. A mercantilist economic model therefore fosters a rigidly hierarchical society in which the majority of the population is dependent on a small elite.

By contrast, a liberal model organizes productive activity toward maximizing profit through exchange in free markets (cf. Wallerstein 1974; Roemer 1982). ${ }^{4}$ Unlike the mercantilist model, the liberal model is not associated with a state that privileges status groups and explicitly imposes hierarchical relations of dependence. Instead, political authorities use the state to uphold private property, encourage commercial production, and enforce the rule of law. Though the state is not directly involved in economic production, it is vital for the provision of the basic infrastructure necessary to sustain a market economy (Smith [1776] 2000).

We use this distinction between mercantilist and liberal models to develop two overarching hypotheses. One concerns the relationship between precolonial development and level of colonialism, and the other concerns

Tuvalu. Finally, former British colonies that merged with non-British colonies at independence-such as British Cameroon and British Somaliland-are not included.

${ }^{4}$ We prefer the label "liberal" to "capitalist" for two reasons. First, capitalism is often understood as a mode of production based on free-wage labor, which is not our main concern. Second, by some definitions, mercantilism is itself a type of capitalist production. To avoid these kinds of confusions, we adopt the label liberal. 
TABLE 1

Timing of Colonialism

\begin{tabular}{|c|c|c|}
\hline Country & $\begin{array}{c}\text { Onset of } \\
\text { Colonialism }\end{array}$ & $\begin{array}{c}\text { Conclusion of } \\
\text { Colonialism }\end{array}$ \\
\hline \multicolumn{3}{|l|}{ Spanish colonies: } \\
\hline Argentina .... & 1580 & 1819 \\
\hline Bolivia $\ldots \ldots \ldots \ldots \ldots$ & 1538 & 1825 \\
\hline Chile ......... & 1541 & 1818 \\
\hline Colombia $\ldots \ldots \ldots \ldots$ & 1536 & 1819 \\
\hline Costa Rica $\ldots \ldots \ldots \ldots$ & 1524 & 1821 \\
\hline Cuba $\ldots \ldots \ldots \ldots$ & 1511 & 1899 \\
\hline Dominican Republic ... & 1493 & 1821 \\
\hline Ecuador .................. & 1534 & 1822 \\
\hline El Salvador .............. & 1524 & 1821 \\
\hline Guatemala .............. & 1524 & 1821 \\
\hline Honduras $\ldots \ldots \ldots \ldots$ & 1524 & 1821 \\
\hline Mexico ................. & 1521 & 1821 \\
\hline Nicaragua $\ldots . . . . . . . . .$. & 1523 & 1821 \\
\hline Panama ......... & 1519 & 1821 \\
\hline Paraguay ........ & 1537 & 1811 \\
\hline Peru $\ldots \ldots \ldots \ldots \ldots \ldots$ & 1533 & 1824 \\
\hline Uruguay $\ldots \ldots \ldots \ldots \ldots$ & 1625 & 1828 \\
\hline Venezuela ............... & 1528 & 1821 \\
\hline \multicolumn{3}{|l|}{ British colonies: } \\
\hline Australia ............... & 1788 & 1901 \\
\hline Bahamas ................ & 1783 & 1973 \\
\hline Bangladesh .............. & $1756 / 1857$ & $1947 / 1971$ \\
\hline Barbados ................. & 1627 & 1966 \\
\hline Belize $\ldots \ldots \ldots \ldots \ldots \ldots$ & 1798 & 1981 \\
\hline Botswana............. & 1885 & 1966 \\
\hline Brunei .................... & 1888 & 1984 \\
\hline Canada $\ldots . . . . . . . . . . . .$. & $1610 / 1763$ & 1867 \\
\hline Cyprus .................. & 1878 & 1960 \\
\hline Egypt .................. & 1882 & $1922 / 1935$ \\
\hline Fiji $\ldots \ldots \ldots \ldots \ldots \ldots \ldots$ & 1871 & 1970 \\
\hline Gambia $\ldots \ldots \ldots \ldots \ldots$ & 1888 & 1965 \\
\hline Ghana ................. & 1874 & 1957 \\
\hline Guyana .................. & 1814 & 1966 \\
\hline Hong Kong ............. & 1842 & 1999 \\
\hline India $\ldots \ldots \ldots \ldots \ldots \ldots$ & $1757 / 1857$ & 1947 \\
\hline Jamaica $\ldots \ldots \ldots \ldots \ldots$ & 1655 & 1962 \\
\hline Kenya $\ldots \ldots \ldots \ldots \ldots \ldots$ & 1886 & 1963 \\
\hline Lesotho ................. & 1884 & 1966 \\
\hline Malawi .................. & 1891 & 1964 \\
\hline Malaysia ................. & $1786 / 1874$ & 1957 \\
\hline Mauritius $\ldots \ldots \ldots \ldots . . . .$. & 1810 & 1968 \\
\hline Myanmar ................ & $1826 / 1885$ & 1948 \\
\hline New Zealand ............ & 1840 & 1907 \\
\hline Nigeria $\ldots \ldots \ldots \ldots \ldots \ldots$ & $1861 / 1885$ & 1960 \\
\hline Pakistan ................ & 1857 & 1947 \\
\hline
\end{tabular}


American Journal of Sociology

TABLE 1 (Continued)

\begin{tabular}{|c|c|c|}
\hline Country & $\begin{array}{c}\text { Onset of } \\
\text { Colonialism }\end{array}$ & $\begin{array}{c}\text { Conclusion of } \\
\text { Colonialism }\end{array}$ \\
\hline Sierra Leone.$\ldots \ldots \ldots \ldots$ & $1787 / 1896$ & 1961 \\
\hline Singapore $\ldots \ldots \ldots \ldots \ldots$ & 1819 & 1959 \\
\hline Solomon Islands ........ & 1893 & 1978 \\
\hline South Africa ........... & 1795 & 1910 \\
\hline Sri Lanka ........ & 1798 & 1948 \\
\hline Sudan .... & 1898 & 1956 \\
\hline Swaziland .............. & 1894 & 1968 \\
\hline Tanzania $\ldots . . . . . . . . . . .$. & 1918 & 1961 \\
\hline Trinidad/Tobago ....... & 1797 & 1962 \\
\hline Uganda $\ldots \ldots \ldots \ldots \ldots$ & 1893 & 1962 \\
\hline United States ........... & 1607 & 1783 \\
\hline Zambia ................ & $1890 / 1923$ & 1964 \\
\hline Zimbabwe $\ldots \ldots \ldots \ldots$ & $1895 / 1923$ & $1965 / 1980$ \\
\hline
\end{tabular}

NoTE. - The dates listed here are approximations. Identifying a single starting point of colonialism is problematic for many cases, given that the initiation of the process was often gradual and informal. For the Spanish-American cases, we date the onset of colonialism with the foundation of major settlements or expeditions that established enduring control over the indigenous population. The initiation of British colonialism is often especially difficult to date. For example, India was clearly under the grip of the English East India Company by the $1750 \mathrm{~s}$, but it was not proclaimed a colony under control from London until 1857. We note several cases in which multiple dates could be used to mark the beginning of British colonialism. The conclusion of colonialism corresponds with the more or less complete defeat and/or withdrawal of colonial authorities rather than simply the declaration of independence.

the relationship between level of colonialism and postcolonial development.

The first hypothesis is that mercantilist and liberal powers impose different levels of colonialism in territories with similar levels of precolonial development. For mercantilist powers, we argue that they are more likely to pursue extensive institutional establishment in comparatively more complex (i.e., more economically and politically developed) precolonial regions; mercantilist powers are less likely to pursue a high level of colonialism in comparatively less complex regions. Our reasoning grows out of the fact that complex precolonial regions exhibit densely settled populations, statelike political organizations, and hierarchical economies that often rely on coercive labor systems. These conditions facilitate the mercantilist goal of extracting resources through the use of a dependent labor force without having to alter radically preexisting economic structures. By contrast, less complex precolonial regions feature hunter-gatherer and simple agricultural societies and thus provide mercantilists with fewer opportunities to build on established economic networks for exploiting indigenous labor. When mercantilist powers colonize less complex soci- 
eties, therefore, they generally do so without imposing a broad range of institutional arrangements and without encouraging large-scale settlement.

Conversely, we argue that liberal economic powers are likely to pursue low levels of colonialism in more complex precolonial regions, and they are likely to pursue high levels of colonialism in less complex precolonial regions. More complex precolonial regions usually exhibit entrenched precapitalist institutions, and these institutions make it difficult for liberal colonizing powers to alter existing economic networks in ways necessary to achieve market-based accumulation. Thus, when confronted with a complex civilization that cannot easily be dislodged, liberal colonizers tend to implant only a limited range of institutions and a small number of settlers. By contrast, less complex precolonial regions marked by huntergatherer or simple agricultural societies can be more readily displaced to make way for the introduction of a broad range of new market institutions and state organizations. We suggest that liberal powers prefer to colonize heavily these less complex societies because they allow authorities and settlers to pursue institutional establishment without having to build on top of or work through preexisting arrangements.

Our second overall hypothesis concerns the effect of level of colonialism on postcolonial development. Because level of colonialism describes a broad range of institutions implanted by colonial occupiers, it is useful to disaggregate this concept into more specific institutions that operate as key mechanisms in shaping postcolonial development. We especially focus on those institutions that regulate (1) commerce and markets (e.g., the extent of free trade), (2) political authority (e.g., the degree to which a rule of law is present), and (3) race and ethnicity (e.g., the degree to which all groups have the same rights). The first is especially important for longrun economic development, the third is especially important for long-run social development, and the second is highly consequential for both. We suggest that the content of these institutions varies across particular levels of mercantilist and liberal colonialism, with major implications for postcolonial development.

For mercantilist colonies, a high level of colonialism greatly inhibits postcolonial development. More extensive mercantilist colonialism shapes economic development through the establishment of trade restrictions, protected merchant guilds, and entrenched actors who benefit from state privileges. In a capitalist world economy, these mercantilist institutions are a serious disadvantage. In terms of social development, a high level of mercantilist colonialism has the additional consequence of establishing labor institutions and sociocultural conventions that transform the indigenous population (or an imported worker population) into an exploited ethnoracial group that often lacks access to health care and education. 
American Journal of Sociology

Insofar as this exploited ethnoracial group represents a large percentage of the total population, overall social performance will be greatly compromised. Finally, mercantilism breeds patrimonial states whose leaders are unable - and usually unwilling — to provide competitive markets, education, a rule of law, health care, and other public goods to nonelite groups. For its part, limited mercantilist colonialism does not allow a territory to fully escape these calamities. But it does mean that the territory will be characterized by weaker and less entrenched mercantilist obstacles, thereby having a higher probability of experiencing socioeconomic development in the postcolonial epoch.

For liberal colonies, conversely, level of colonialism is positively related to socioeconomic development. More extensive liberal colonialism tends to direct production toward international trade, which encourages competitiveness within a capitalist world economy and may also benefit human well-being by providing greater resources to state and societal actors. In addition, higher levels of liberal colonialism can lead to the establishment of coherent administrative, juridical, and police institutions that provide the basic infrastructure for functioning markets. These institutions enhance socioeconomic development because broad societal groups often benefit from a state's ability to enforce a rule of law, administrate effectively, and provide public goods such as clean water and education. By contrast, low levels of liberal colonialism have very negative effects on development. When liberal colonizers do not implant extensive institutions, they generally rule through colonial intermediaries who are granted authority over the local population in exchange for their collaboration. In turn, by empowering indigenous elites, limited liberal colonialism creates patron-client systems characterized by hierarchy, dependence, and the absence of a rule of law. Moreover, a low level of liberal colonialism does not introduce state institutions that provide the necessary infrastructure for coherent markets and social development. Rather, colonial authorities impose a constrained and highly select set of marketlike institutions that channel resources to individuals in strategic political positions.

The overall relationships that inform this theory can be summarized in a three-step model (see fig. 1). In the model, the association between precolonial level of development (step 1) and postcolonial level of development (step 3) is negative for both mercantilist and liberal colonizers. However, the directions of the causal processes that mediate this relationship are inverted. Thus, for the mercantilist colonies, initial backwardness is an advantage because it leads to less extensive colonialism, which in turn has comparatively positive effects on long-run development. By contrast, for the liberal colonies, a low level of precolonial development 


\section{a. Mercantilist Colonialism}

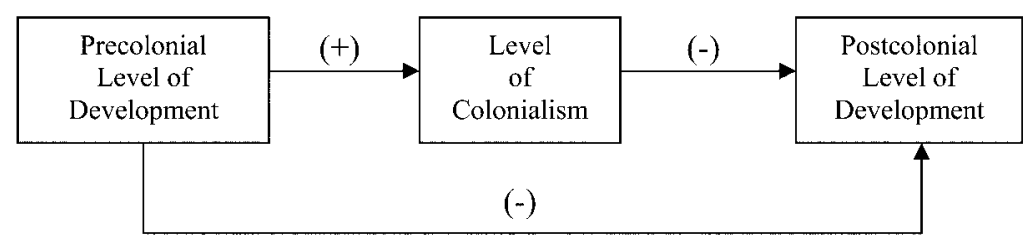

\section{b. Liberal Colonialism}

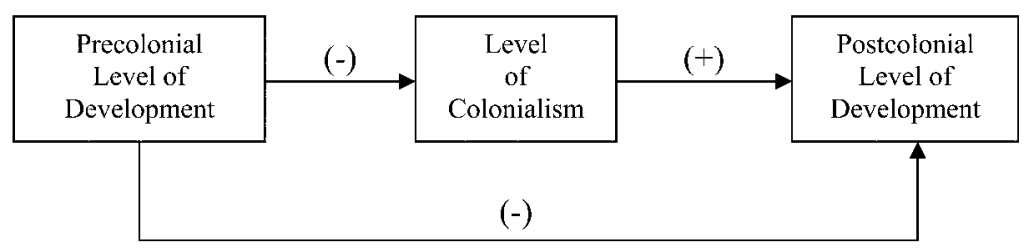

Fig. 1.-A model of colonialism and development

is an advantage because it produces more extensive colonization, which has comparatively positive effects on postcolonial development.

In evaluating this theory, we focus on two colonial powers-Spain and Britain - that approximate the ideal-types of economic models. In the 16th and 17 th centuries, Spain was characterized by a mercantilist economic model (Larraz López 1963; Vicens Vives 1969; Walker 1979). Although by the mid-18th century Spain moved toward more capitalistic economic arrangements, the trade monopoly in Cadiz remained the key bureaucratic structure, and monarchs and ministers continued to fixate on bullion extracted from the New World as a central means to stimulate the economy. In comparison, Britain was never as mercantilist in orientation as Spain, even in the 17 th century, when it first embarked on a colonial project (Fieldhouse 1966). Moreover, the vast majority of British colonialism occurred after the mid-18th century, by which time Britain was characterized by a liberal economic model that explicitly advocated free trade and that conceptualized the state as a tool for ensuring law and order.

We do not claim that Britain and Spain perfectly correspond to the 
American Journal of Sociology

ideal-types of mercantilist and liberal economic models. For example, Spain gradually became more liberal during the 18th century, and it implanted some capitalistic institutions in previously marginal colonies, such as Argentina. Indeed, these regions that experienced the introduction of more liberal institutions often experienced more success in the postcolonial period. Analogously, we note that the early British colonies in the Caribbean and the American South saw the introduction of coercive labor institutions, and that this quasi-mercantilist period left an enduring social legacy. Yet, our main goal is not to explore variation over time in the extent to which Spain and Britain correspond to the two ideal-types, but rather to evaluate whether the evidence is broadly consistent with a theory that assumes Spain is mercantilist and Britain is liberal.

Nor do we wish to suggest that the economic model of the colonizer and the level of development of the colonized region can completely explain the outcomes examined here. Rather, during particular historical periods, specific events and processes within colonizers-demographic trends, religious changes, and politics of the day-also affected colonial patterns. Likewise, in terms of conditions in the colonial regions, variables such as the extent of exploitable resources and the prevailing disease environment shaped how both colonial authorities and settlers approached institutional establishment. Nevertheless, our goal is to offer a parsimonious framework that can coherently explain a substantial portionthough certainly not all—of the variation in level of colonialism and development across the Spanish and British colonies. This framework also provides a basis for thinking about anomalous cases that do not correspond with the predicted outcomes. For example, below we shall see that liberal Britain extensively colonized Hong Kong, despite the fact that Hong Kong was a densely populated and highly complex society. We explain this anomaly in light of the organization of the economy in precolonial Hong Kong, which featured open markets and free labor rather than the typical precapitalist institutions and therefore attracted British colonization efforts. In this sense, Hong Kong is an exception to the predicted pattern, but also a case that still conforms to the spirit of our overarching theoretical argument.

Finally, although we focus on the Spanish and British colonies, our analysis leaves the door open for future research to examine how the economic orientation of other colonizers shaped the extent of their colonial efforts and the kinds of institutional legacies they left behind. In this regard, it is worth noting that colonial powers generally became more liberal over time as global capitalism gained momentum. Likewise, precolonial regions generally have become more complex as global interconnectedness stimulated the decline of hunter-gatherer and semisedentary societies (Wallerstein 1974; Wolf 1982). Thus, increasingly liberal powers 
colonize increasingly developed societies. In this context, we would expect colonialism to be accompanied by low levels of institutional transfer, given that liberal colonizers prefer to pursue only limited institutional establishment in complex societies. In turn, our theory suggests that these low levels of transfer will have negative effects on postcolonial development. Our theoretical model therefore offers new insights for exploring how colonialism evolves across world-historical time in tandem with changes in global economic organization and interconnectedness.

\section{THE ESTABLISHMENT OF COLONIALISM}

In this section, we consider how preexisting levels of development shape the extent of Spanish and British colonialism. To assess precolonial development, we focus on the size and organization of non-European societies at the onset of colonialism. We especially distinguish between more complex and populous societies organized politically as protostates versus less complex and sparsely populated societies characterized by village farming communities or hunter-gatherer bands. To evaluate level of colonialism, we consider the volume of migration from the colonizing nation, the size and reach of the colonial state apparatus, the pervasiveness of labor and stratification systems implemented by the colonizers, and the extent to which dominant cultural orientations of the colonizing nation gain prevalence within a colony. Territories with higher levels of colonialism are marked by more settlers, a more significant colonial bureaucracy that reaches into society to uphold systems of property and labor, and the presence of more religious organizations and other cultural institutions modeled on the colonizing nation.

\section{Spanish Colonies}

The Spanish most extensively colonized those areas of the New World where preexisting civilizations were located. At the time of the conquest, the Aztec Empire ruled the highlands of central Mexico and parts of Guatemala, and the Inca Empire dominated much of modern Ecuador, Peru, and Bolivia. These densely settled and economically advanced societies controlled important deposits of precious metals and mobilized resident populations for labor services (e.g., Andrien 2001; Carrasco 1976; D'Altroy 2002; Rostworowski 1988; Smith 1996; Townsend 2001). At the same time, these historical civilizations were not marked by high levels of social development; in fact, their consolidation of settled agriculture and imposition of state-led tribute extraction likely caused a general deterioration of human health (Steckel and Rose 2002). The simultaneous 
American Journal of Sociology

presence of large quantities of precious metals and readily exploitable indigenous labor, however, made the regions the obvious choice of settlement for Spanish conquerors who had become accustomed to the occupation of prosperous societies during Spain's "reconquista" of Muslim Granada.

A small number of cities in Mexico and the Andes received most of the settlers during the early and midcolonial period (Boyd-Bowman 1976; Mörner 1976; Sánchez-Albornoz 1974). In these center areas, the new settlers established extensive economic, political, and sociocultural institutions. ${ }^{5}$ For example, slavery was long practiced in the Iberian Peninsula, and Spanish authorities in the New World combined this instrument with precolonial models of labor drafts to secure a workforce for the mines and large agrarian estates. Likewise, the practice of granting monopolistic guild organizations control over the import-export business and local finance was extended to the New World. Beyond economic institutions, the center areas also featured the most significant implantation of Spanish political institutions. In the Viceroyalty of New Spain and the Viceroyalty of Peru, top-ranking bureaucrats and military officers from Spain oversaw general administration, legal procedures, public works, and defense. Moreover, the Catholic Church-in tandem with various religious ordersorganized large-scale and well-orchestrated evangelization campaigns in the colonial centers (Hoberman and Socolow 1986). The purity of blood doctrine, already employed during the reconquista, gained a prominent role in the jurisdictions of the colonial administration. The Spanish used this ideology to justify their elite status and cement their distinction from "Indians," a category they invented to designate all of the people indigenous to the Americas.

Before the Spanish arrived, village farming and nonsedentary groups that lacked significant surplus accumulation and a complex division of labor characterized much of the New World outside the Aztec and Inca empires. Although these societies often outperformed the historical civilizations on key social indicators (Steckel and Rose 2002), they were precisely the places where the Spanish did not settle in large numbers (Newson 1985; Sánchez-Albornoz 1974). For example, the southern parts of Central America, northern regions in South America, and the Southern Cone of modern Argentina, Chile, and Uruguay were characterized by smaller-scale agrarian settlements and hunter-gatherer societies. Many of

\footnotetext{
${ }^{5}$ The regions of modern Guatemala and Colombia also were significant Spanish colonial territories. Guatemala was important because the former Mayan empire left behind dense and complex indigenous societies; Colombia attracted attention because of its gold deposits, though the lack of a dense indigenous population in the region eventually led the Spanish to employ African slaves to work the mines.
} 
the most enduring Spanish sociocultural imprints in these areas were left by religious orders and their missionaries, not the colonial state. Until well into the colonial period, the Spanish crown paid little attention to these peripheral regions, as revealed by the relative absence of highranking royal administrators, church officials, and lower bureaucrats (Mahoney 2003). Hence, key parts of the empire in Latin America did not see the entrenchment of mercantilist institutions during the colonial epoch.

The Caribbean islands that were colonized by the Spanish-most important, Cuba and the Dominican Republic - did not feature highly complex civilizations before the conquest (though the Arawaks of Hispaniola were sizable in number). Moreover, Spanish warfare and diseases rapidly and almost completely destroyed those societies that did exist. Nevertheless, especially through the introduction of African slaves and plantation agriculture, which was accompanied by the appearance of royal officials and mercantilist elites in larger towns, Cuba and the Dominican Republic remained reasonably important Spanish colonies within the empire, even as the center of gravity shifted toward Mexico and Peru (Lockhart and Schwartz 1983; Pérez 1988).

In summary, before the 18th century, the Spanish colonized most heavily those areas where a complex civilization was located. We can see this pattern in table 2, which estimates levels of precolonial development and levels of colonialism for the modern countries of Spanish America. The Spearman correlation coefficient for these two variables is .85 . Of the 18 cases, 15 are fully consistent with theoretical expectations, and the three exceptions are not completely out of line: Cuba and the Dominican Republic are scored as having low levels of precolonial development but experienced intermediate levels of colonialism; Nicaragua had an intermediate level of precolonial development but a low level of colonialism.

The inverse relationship between precolonial development and level of Spanish colonialism is also present when proxy statistical variables are used. We employ the absolute size of the precolonial population to measure precolonial development (see table 2), which is correlated with our own estimate of precolonial level of development $(\rho=.79) .{ }^{6}$ To estimate levels of colonialism, we draw on Palmer's (1977) rankings for level of "Spanish

\footnotetext{
${ }^{6}$ The statistical literature is usually concerned with population density (i.e., persons per unit of land) rather than absolute population. For the Spanish-American cases, population density for 1492 is positively correlated with level of colonialism, though the correlation is fairly weak $(\rho=.32)$. We choose not to use population density because it produces clearly inaccurate estimates of levels of precolonial development in Spanish America. For example, in 1492 Mexico was only the fifth most densely populated territory, and Peru was tied for only seventh. These levels are inconsistent with what we know about precolonial development. By contrast, absolute population size corresponds well with established understandings of precolonial levels of development.
} 
American Journal of Sociology

TABLE 2

Levels of Precolonial Development and Colonialism: Spanish Colonies

\begin{tabular}{|c|c|c|c|c|c|}
\hline Country & $\begin{array}{c}\text { Level of } \\
\text { Precolonial } \\
\text { Development }\end{array}$ & $\begin{array}{c}\text { Level of } \\
\text { Colonialism }^{\mathrm{a}}\end{array}$ & $\begin{array}{l}\text { Precolonial } \\
\text { Population } \\
\text { ca. } 1492 \\
(\text { in } 1000 \mathrm{~s})^{\mathrm{b}}\end{array}$ & $\begin{array}{l}\text { Palmer's } \\
\text { Rankings } \\
\text { for Colonial } \\
\text { Influence } \\
(1=\text { most })^{c}\end{array}$ & 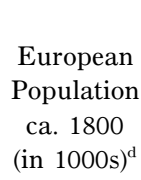 \\
\hline Argentina & Low & Low & 900 & 13 & 318 \\
\hline Bolivia $\ldots . . . .$. & High & High & 2,600 & 4.5 & 419 \\
\hline Chile ........... & Low & Low & 1,000 & 12 & 396 \\
\hline Colombia ....... & Intermediate & Intermediate & 3,000 & 4.5 & 664 \\
\hline Costa Rica .... & Low & Low & 400 & 16 & 59 \\
\hline Cuba $\ldots \ldots \ldots . . .$. & Low & Intermediate & 110 & 7 & 272 \\
\hline \multicolumn{6}{|l|}{ Dominican } \\
\hline Republic .... & Low & Intermediate & 500 & 6 & \\
\hline Ecuador ....... & High & High & 1,700 & 9 & 148 \\
\hline El Salvador ... & Intermediate & Intermediate & 750 & 8 & 138 \\
\hline Guatemala .... & High & High & 2,000 & 3 & 242 \\
\hline Honduras ..... & Intermediate & Intermediate & 850 & 11 & 72 \\
\hline Mexico ........ & High & High & 17,200 & 1 & 2,451 \\
\hline Nicaragua ..... & Intermediate & Low & 825 & 14 & 76 \\
\hline Panama...... & Low & Low & 800 & 10 & \\
\hline Paraguay ....... & Low & Low & 370 & 17 & 76 \\
\hline Peru $\ldots \ldots \ldots \ldots$ & High & High & 8,200 & 2 & 528 \\
\hline Uruguay ........ & Low & Low & 160 & 18 & 39 \\
\hline Venezuela ..... & Intermediate & Intermediate & 1,000 & 15 & 371 \\
\hline
\end{tabular}

${ }^{a}$ Data for level of precolonial development and level of colonialism are our estimates based on our previous and current research on the region. See the text for discussions of particular cases.

${ }^{\text {b }}$ Data for precolonial population ca. 1492 are from Mahoney and vom Hau (2003) except for Cuba, which is Pérez's estimate (1988, p. 20), and the Dominican Republic, which is half of Denevan's (1992, p. xxiii) estimate for Hispaniola.

${ }^{\mathrm{c}}$ Data are from Palmer $(1977,1980)$.

${ }^{\mathrm{d}}$ Data for European population ca. 1800 are derived from Mahoney and vom Hau (2003) by subtracting their estimates of the size of the indigenous population in 1800 from the size of the total population in 1800. This method inflates the size of the European population for cases with a substantial African population, especially Colombia. Cuban data are from Pérez (1988, p. 63).

colonial penetration," which he derives by aggregating data for 1800 concerning bullion production, bishopric revenue, city population, total population, population density, and total trade. His measure is strongly correlated with our own estimate of level of colonialism $(\rho=.82)$. Furthermore, as a second statistical proxy for level of colonialism, we consider the size of the European population at the end of the colonial period in 1800 .

Precolonial population size and Palmer's estimate for level of colonialism are positively related to one another $(\rho=.65)$; likewise, precolonial population size and European population size in 1800 are very strongly related $(r=.94)$. These findings again strongly suggest that higher levels of colonialism occurred in more complex and populous areas. 
Colonialism and Development

\section{British Colonies}

The British Empire was established over a longer period of time and was more disparate than the Spanish Empire, making generalizations more problematic. Yet, for analytic purposes, British colonialism can be divided into four types that generally correspond to different levels of colonialism. First, the most extensive form was settler colonialism, where permanent residents transplanted a broad range of institutions from Britain into the colonies without preserving precolonial arrangements. The British pursued this strategy only in sparsely populated regions that featured a favorable disease climate. Second, when complex precolonial societies were organized around protostates, the British usually pursued indirect colonialism, allowing precolonial leaders to maintain political and legal power over their subjects, while requiring them to report and pay taxes to the colonial administration. This uneasy combination of central bureaucratization and peripheral patrimonialism was the hallmark of indirect British rule, and it was the norm in Africa, though it could also be found in parts of Asia. In sharp contrast to settler colonialism, indirect colonialism entailed a low level of institutional transfer from Britain.

Between the extremes of settler colonialism and indirect colonialism, we identify two intermediary types: direct colonialism and hybrid colonialism. With the former, the British implanted a colonial state that was unified, bureaucratically organized, and of territory-wide reach. However, direct colonialism did not feature large-scale and permanent British settlement, often because of the prevailing disease climate. The British pursued direct colonialism in trade-oriented colonies, such as Hong Kong and Singapore, and plantation colonies, such as the West Indies. Finally, the hybrid colonies combined indirect colonialism with either settler or direct colonialism. Indirect colonialism went together with settlement in a few African colonies, South Africa being the most notable example. Indirect colonialism was fused with direct colonialism in certain Asian and Pacific colonies, including those too large to be easily controlled by a central bureaucracy, such as India.

The four types of colonialism were generally concentrated both geographically and temporally. The British first established settler and directly ruled plantation colonies in the Americas and Australasia, then they colonized Asian territories through direct and hybrid forms of rule, and finally they colonized sub-Saharan Africa, Borneo, and a few Pacific Islands through indirect and hybrid forms of rule.

North America and Australasia.-The first British colonies (the future United States, Canada, and Barbados) were all settler colonies. The introduction of cash crops and slavery, however, quickly transformed Barbados and the territories of the American South from settler colonies of 
American Journal of Sociology

small farmers to plantation colonies in which British settlers ruled directly over an imported labor force. A century or more later, the British established two additional settler colonies in Australia (1788) and New Zealand (1840).

Before the onset of colonialism, these regions displayed sparsely populated precolonial societies without statelike organization-the various chiefdom societies of North America, the aboriginal groups of Australia, and the Maoris in New Zealand (Denoon 1983). Diseases and warfare brought by British colonization efforts decimated these populations, and those that remained were systematically isolated and oppressed whenever they came into contact with frontier settlers. In turn, the removal of these societies set the stage for the wholesale introduction of British institutions; the settlement colonies evolved into little Great Britains, albeit with a more rugged character, a more segmented religious structure of often competing communities, and without a powerful landed aristocracy. Because of the latter, the colonies tended to have active, participatory political institutions and more egalitarian economies, and in this sense they were more liberal than the metropolis itself (Ferguson 2002).

Like the settler colonies, the plantation colonies of the West Indies were an ideal area for British settlement because they lacked complex precolonial societies at the advent of colonization-the result of either the absence of indigenous peoples or their speedy demise after the arrival of Europeans. From the early 17 th century until the late 18th century, a substantial portion of all British settlers to the New World migrated to these islands, especially Barbados and Jamaica (Galenson 1996). However, high white mortality rates and low white fertility rates eventually more than offset these migration inflows. In addition, a tiny British elite soon monopolized sugar production, leading potential settlers to believe that the West Indies offered no real economic opportunities.

In the mid-17th century, African slaves became the majority of the West Indies population, and extractive institutions were constructed to exploit their labor. As a result, these colonies departed significantly from the other settler colonies. The laboring classes were more marginalized-politically and economically - than were their settler counterparts (Beckford 1983). Even so, the sheer length of British colonialism in the West Indies combined with emancipation and liberalizing reforms beginning in the 1830s did promote the introduction of participatory political institutions (Lange 2003; Lee 1967). Over time, these colonies witnessed the construction of colonial administrations with loyalties to Great Britain and the decreasing influence of plantation elites. Under the system of direct colonialism that emerged, the British installed police structures and court systems to protect property rights and uphold the political liberties and rights of common citizens (Lewis 1968). 
Asian colonies.-Britain's Asian colonies generally show intermediate and high levels of precolonial development, and thus our theoretical expectation is that these colonies will be subject to intermediate to low levels of institutional establishment. In fact, however, British occupation often resulted in intermediate to high levels of colonial influence because of the presence of exploitable resources and markets. The Asian colonies therefore only sometimes conform to the predicted inverse relationship between precolonial development and level of British colonialism.

Hong Kong and Singapore experienced among the greatest levels of colonial influence within the British Empire. They were ruled purely through direct administration and featured liberal economies based on open markets and free labor (Ngo 1999; Ryan 1976). At the time of colonial conquest, however, Hong Kong was densely populated and part of one of the world's most developed empires (Roberts, Ling, and Bradshaw 1992). Singapore, on the other hand, was lightly populated, although it had historically been on the fringes of the Malacca and Johore Sultinates (LePoer 1991; Ryan 1976). Despite their prior development, liberal Britain heavily colonized these areas because of their strategic military and trade locations. Moreover, the small territorial size of Hong Kong and Singapore facilitated the bureaucratic task of imposing direct colonialism over the indigenous populations.

Great Britain also established direct colonialism in Ceylon (Sri Lanka) even though it featured high levels of precolonial development. Precolonial Ceylon was ruled through the powerful and centralized Kandyan Kingdom, which was weakened by Portuguese and Dutch interference prior to British colonialism, yet still required considerable time and resources for eventual British conquest. Because of its commercial potential and strategic location, the British imposed centralized administrations in densely populated Ceylon. Through this mostly direct form of rule, the colonial state transferred important legal-administrative institutions (de Silva 1997; Jeffries 1962; Nyrop et al. 1971). In terms of economic institutions, a substantial number of tea plantations could be found in colonial Ceylon, yet these were enclaves within a larger network of market relations, not totalizing institutions that shaped nearly all aspects of life as in the West Indies (Beckford 1983).

Forms of hybrid colonialism combining direct and indirect rule were used in colonial India, growing out of Britain's unwillingness to dominate vast and highly populated territories through direct means. Although the Great Mughal Empire of roughly modern Pakistan, India, and Bangladesh had declined by the onset of British colonialism, a number of kingdomsespecially Bengal and Hyderabad-displayed substantial economic and political power (Bayly 1988; Kulke and Rothermund 1998). As the East India Company came to exercise quasi-colonial control in the 18th and 
American Journal of Sociology

early 19th centuries, therefore, it did so against the backdrop of a complex agrarian-bureaucratic political order that featured centralized administration, permanent armed forces, and relatively efficient tax collection (Stokes 1973).

In 1857, indigenous elites and disgruntled soldiers led a major revolt against British rule, which compelled Britain to make India an official colony under control from London (Bayly 1988; Masani 1960). The revolt also taught colonial authorities that they could hardly expect simply to abolish or even ignore local institutions without devastating consequences. The British solution was to strengthen alliances with elites and to use them to collect taxes and maintain political order. Thus was born a hybrid colony that combined indirect and direct forms of colonialism.

Some 600 princely states comprising approximately two-fifths of colonial India were ruled indirectly. The remainder of the colony continued to be dominated by a direct form of administration that did not incorporate indigenous institutions into the overall system of governance $(\mathrm{Ku}-$ mar 1998; Marshall 1968). Because of the minuscule size of the colonial administration, however, both directly and indirectly ruled areas experienced rather low levels of colonial influence. ${ }^{7}$ The colonial state never extended down to the community level, preexisting religious and sociocultural institutions remained intact, and patrimonial intermediaries were left as the primary governors even in directly ruled areas (Edwardes 1967; Kumar 1989). India, Bangladesh, Myanmar, and Pakistan therefore experienced low to intermediate levels of colonial influence. ${ }^{8}$

The British also combined direct and indirect forms of rule in Malaya. Although Portuguese and Dutch interference had destroyed the Malacca Sultanate, Malaya still contained a dozen large and relatively prosperous sultanates at the onset of British colonialism. During most of the colonial period, British colonizers maintained very powerful legal-administrative institutions in certain parts of the Malay Peninsula (the Straits Settlements and the Federated Malay States). However, these institutions were much weaker in the Unfederated Malay States, where the British used various indirect forms of rule (Brown and Ampalavanar 1986; Heussler 1981; Zawawi 1998; Ryan 1976). Only as independence approached was a more centralized and bureaucratic system of rule closer to direct colonialism

\footnotetext{
${ }^{7}$ The local state of Awadh, which was directly ruled, had one colonial official for every 295,300 people in 1872. All of colonial India had a ratio of $1: 267,300$ in 1881 . By contrast, Nigeria-which had the fewest officials per capita in British Africa-had a ratio of $1: 51,800$ in the 1930s (Fisher 1991, p. 8).

${ }^{8}$ Colonial Burma-present-day Myanmar-was ruled as a part of the Indian administration until 1937 and therefore has many similarities: one-third of the colony experienced indirect rule, and the colonial administration was quite limited in size.
} 
constructed, largely because the colonial state extended its territorial reach in response to a prolonged guerrilla insurgency.

Sub-Saharan Africa and the Pacific.-The final phase of British colonialism occurred in the Pacific, Borneo, and especially Africa, and it almost always established indirect forms of rule in complex precolonial societies. As such, these colonies conform to the theoretical model: high levels of precolonial development promoted low levels of British colonialism.

In sub-Saharan Africa, British colonies were founded in modern Botswana, Gambia, Ghana, Kenya, Lesotho, Malawi, Nigeria, Sierra Leone, South Africa, Sudan, Swaziland, Tanzania, Uganda, Zambia, and Zimbabwe. Most of these regions were characterized by complex and populated precolonial societies, which discouraged British migration and institutional establishment. ${ }^{9}$ Instead British colonizers pursued indirect rule, exercising power through customary institutions and without completely displacing existing political structures, courts, and landholding patterns (Fage 2002; July 1998). In fact, usually only a few hundred British administrators were responsible for overseeing indirect rule in each colony. This form of colonialism, however, did not leave local social structures unchanged. Rather, British colonialism radically transformed local social and political structures by granting chiefs substantial power and upholding their authority under nearly all circumstances. Thus, although indirect colonialism supposedly worked through only precolonial channels, the local institutions used by the British were to varying extents colonial constructs themselves (Mamdani 1996).

At the onset of colonialism, West Africa contained a number of political units along the coasts with ties to larger kingdoms in the hinterland. In modern Ghana, the Ashanti Kingdom participated in the coastal slave trade with European merchants and specialized in long-distance exchange along trans-Saharan trade routes (Ajayi and Crowder 1971; Fage 2002; Oliver 1999). Although early on the British did try to settle the area, the combination of local resistance and high mortality rates made these efforts unprofitable and undesirable. Instead, the British allowed the Ashanti chiefs largely unconstrained control over administration, not enforcing taxation until the 1930s and not disrupting most landholding patterns at

${ }^{9}$ The British colonies in Africa correspond nicely with areas that Oliver and Atmore (2005) identify as African states in 1884 (see also Collins, Burns, and Ching 1994, p. 6D). More generally, we judge African societies to be complex and populous in light of other precolonial societies, including those of Latin America in roughly 1500. Given this frame of comparison, precolonial Africa was actually more populated than precolonial Latin America. For example, sub-Saharan Africa in 1900 had 4.4 persons per square kilometer, whereas Latin America in 1500 had only 2.2 persons. See Herbst (2000, p. 16). 
American Journal of Sociology

least until the cocoa boom in the late 1920s. In precolonial Nigeria, the Sokoto Caliphate in the north brought together various emirates under Islamic rule, while the diffuse Yoruba Empire linked coastal settlements with political groups in the interior through the powerful Kingdom of Oyo. The British were hardly prepared to commit the resources necessary to govern Nigeria's approximately 20 million people; rather, a few hundred officials worked with the existing power structures of Yorubaland and the Islamic north. Although each colony differed in minor ways, this process of conquest, cooptation, and colonial rule through local elites occurred throughout the British Empire in eastern and southern Africa, and it allowed the British a low-cost means of ruling vast territories with relatively large and complex indigenous populations (Alpers 1975; Crowder 1968; Ibrahim 1985; Kaniki 1985; Oliver and Atmore 2005; Wolff 1974; Wrigley 1996).

In a few cases, specifically South Africa, Zimbabwe, Kenya, and Zambia, the British established a hybrid form of indirect settler colonialism. Whereas the full-blown settler colonies featured a "frontier of exclusion" that shut out indigenous groups, these indirect settler colonies were marked by a "frontier of inclusion" between settlers and indigenous labor situated within the same territory (Abernethy 2000, p. 56). The white settler and indigenous populations lived under separate institutions-the settlers in direct systems of colonialism, the Africans in indirect systemsyet the former depended on the latter for labor. Thus, especially in South Africa, British indirect settler colonialism resembled Spanish colonialism in the more central areas, even though Britain in most cases did not follow Spain's mercantilist restrictions on trade and commerce.

The British also occupied a few Pacific islands with substantial indigenous populations-Fiji and the Solomon Islands-during its final phase of colonialism. At the onset of British domination, numerous chiefdoms were present in both Fiji and the Solomon Islands, those on Fiji being considerably larger than those on the Solomon Islands. Like the indirect settler colonies in Africa, a bifurcated system of rule was created: the British colonial state indirectly ruled the indigenous populations of Fiji and the Solomon Islands, while British plantation elites directly governed commercial enclaves (Bennett 1987; Gorman and Mills 1994). The larger plantations and fairly substantial administration in colonial Fiji indicate an intermediate level of colonial influence that corresponds with this region's intermediary level of precolonial development. On the other hand, the Solomon Islands, which was a marginal colony, experienced lower levels of colonialism than expected, given its low level of precolonial development.

Sarawak, North Borneo, and Brunei, all of which are located on the island of Borneo, also became colonies during this final period. Sarawak 
and North Borneo were sparsely populated prior to colonization and experienced only low levels of colonial influence. Eventually, however, the two merged with Malaya, becoming exposed to a more centralized and direct form of colonialism during the independence period.$^{10}$ Brunei, which had been an extensive empire stretching as far as the Malay Peninsula and the Philippines, fell under British control after conquests whittled its territory down to little more than a city-state. As in Malaya, the sultan remained only a figurehead, and the British usurped considerable legal and administrative duties. Thus, the British colonies on Borneo are similar to several other colonies in Asia as their levels of colonialism are not inversely related to their level of precolonial development.

Discussion.-From a bird's-eye perspective the extent of British colonialism is inversely related to level of precolonial development. Notably, however, British colonial Asia as a whole does not conform to this generalization. The British heavily colonized many of these populous and developed territories because of some combination of their small size, strategic trade location, and resource endowments. In this sense, because the Asian colonies offered good possibilities for capitalist accumulation, the British were drawn to impose direct colonialism despite the evident difficulties of doing so.

We can infer the overall relationships from table 3, which includes data on precolonial levels of development, precolonial population density, and the percentage of total population comprised by Europeans at the end of the colonial period. In contrast to the Spanish colonies, the relationship between precolonial development and the level of colonialism is negative $(\rho=-.37)$, showing that areas with lower levels of development generally experienced higher levels of colonialism. The relationship, however, is relatively weak because the Asian and Pacific colonies actually exhibit a positive relationship between precolonial development and level of colonialism. ${ }^{11}$ Without the Asian and Pacific colonies, the relationship is considerably stronger $(\rho=-.65)$.

Population density at the onset of colonialism is an alternative measure

${ }^{10}$ Overall, Malaysia had an intermediate level of colonialism as well as an intermediate level of precolonial development, and therefore the case supports our theoretical expectations. Yet, a closer look shows that the subcomponents of Malaysia actually do not confirm these expectations: Malaya had relatively high levels of precolonial development, yet intermediate to high levels of colonial influence, and North Borneo and Sarawak had low levels of precolonial development, yet low levels of colonial influence.

${ }^{11}$ The Asian and Pacific colonies are Bangladesh, Brunei, Fiji, Hong Kong, India, Malaysia, Myanmar, Pakistan, Singapore, the Solomon Islands, and Sri Lanka. For these cases, the correlation between precolonial level of development and level of colonialism is .15 . 
TABLE 3

Levels of Precolonial Development and Colonialism: British Colonies

\begin{tabular}{|c|c|c|c|c|}
\hline Country & $\begin{array}{c}\text { Level of } \\
\text { Precolonial } \\
\text { Development }\end{array}$ & $\begin{array}{c}\text { Level of } \\
\text { Colonialism }^{\mathrm{a}}\end{array}$ & $\begin{array}{c}\text { Precolonial } \\
\text { Population } \\
\text { Density } \\
\left(\text { persons per } \mathrm{km}^{2}\right)^{\mathrm{b}}\end{array}$ & $\begin{array}{l}\text { European } \\
\text { Population } \\
\text { at End of } \\
\text { Colonialism } \\
(\% \text { total })^{c}\end{array}$ \\
\hline Australia ....... & Low & High & .03 & 98.7 \\
\hline Bahamas ....... & Low & Intermediate & .10 & 11.2 \\
\hline Bangladesh ..... & High & Low-intermediate & 176.69 & $<.1$ \\
\hline Barbados ......... & Low & Intermediate & 2.32 & 5.1 \\
\hline Belize $\ldots \ldots \ldots \ldots$ & Low & Intermediate & .44 & 2.9 \\
\hline Botswana ....... & Intermediate & Low & .21 & 1 \\
\hline Brunei .......... & High & Intermediate & 3.8 & 7.3 \\
\hline Canada .......... & Low & High & .02 & 96.8 \\
\hline Cyprus & High & Intermediate-high & 20.56 & 1.2 \\
\hline Egypt ............ & High & Low-intermediate & 7.53 & \\
\hline Fiji $\ldots \ldots \ldots \ldots$ & Intermediate & Low-intermediate & 6.02 & 2.7 \\
\hline Gambia $\ldots . . . .$. & Intermediate & Low & 30 & $<.1$ \\
\hline Ghana .......... & High & Low & 10.99 & $<.1$ \\
\hline Guyana .......... & Low & Intermediate & .1 & 2.9 \\
\hline Hong Kong ..... & High & Intermediate-high & 172.72 & .7 \\
\hline India $\ldots \ldots \ldots \ldots$ & High & Low-intermediate & 63.57 & $<.1$ \\
\hline Jamaica ........ & Low & Intermediate & .92 & 1.1 \\
\hline Kenya & Low & Low-intermediate & 5.71 & .5 \\
\hline Lesotho .......... & Intermediate & Low & 5.77 & .3 \\
\hline Malawi ......... & Intermediate & Low & 7.97 & .3 \\
\hline Malaysia ....... & Intermediate & Intermediate & 3.04 & .2 \\
\hline Mauritius ...... & Low & Intermediate & 0 & .9 \\
\hline Myanmar ...... & High & Low-intermediate & 12.17 & $<.1$ \\
\hline New Zealand ... & Low & High & .37 & 94.7 \\
\hline Nigeria $\ldots . . . \ldots$ & High & Low & 21.41 & $<.1$ \\
\hline Pakistan ........ & High & Low-intermediate & 14.27 & $<.1$ \\
\hline Sierra Leone .... & Intermediate & Low & 23.74 & $<.1$ \\
\hline Singapore $\ldots . .$. & Low & Intermediate-high & .5 & 1 \\
\hline \multicolumn{5}{|l|}{ Solomon } \\
\hline Islands & Low & Low & 3.36 & .7 \\
\hline South Africa .... & Intermediate & Intermediate-high & 1.23 & 21.4 \\
\hline Sri Lanka ...... & High & Intermediate & 34.81 & $<.1$ \\
\hline Sudan & High & Low & 2.53 & $<.1$ \\
\hline Swaziland ........ & Intermediate & Low & 4.94 & 1.4 \\
\hline Tanzania ....... & Intermediate & Low & 4.53 & .3 \\
\hline \multicolumn{5}{|l|}{ Trinidad/ } \\
\hline Tobago ....... & Low & Intermediate & 3.9 & 4.2 \\
\hline Uganda .......... & High & Low & 15.22 & $<.1$ \\
\hline United States ... & Low & High & .09 & 81.2 \\
\hline
\end{tabular}


Colonialism and Development

TABLE 3 (Continued)

\begin{tabular}{|c|c|c|c|c|}
\hline Country & $\begin{array}{c}\text { Level of } \\
\text { Precolonial } \\
\text { Development }{ }^{\mathrm{a}}\end{array}$ & $\begin{array}{c}\text { Level of } \\
\text { Colonialism }^{\mathrm{a}}\end{array}$ & $\begin{array}{c}\text { Precolonial } \\
\text { Population } \\
\text { Density } \\
\left(\text { persons per } \mathrm{km}^{2}\right)^{\mathrm{b}}\end{array}$ & $\begin{array}{c}\text { European } \\
\text { Population } \\
\text { at End of } \\
\text { Colonialism } \\
(\% \text { total })^{c}\end{array}$ \\
\hline Zambia & Intermediate & Low & 1.01 & 3 \\
\hline Zimbabwe ..... & High & Low-intermediate & 1.29 & 7.9 \\
\hline
\end{tabular}

${ }^{a}$ Data for level of precolonial development and level of colonialism are our estimates based on our previous and current research on British colonialism. See the text for discussions of particular cases.

${ }^{\mathrm{b}}$ Data for this variable are estimated from McEvedy and Jones (1978), Kuczynski (1939, 1948, 1949, 1953), British Colonial Office (1953, 1955, 1958), and Roberts et al. (1992). The indigenous population on most former British colonies in the Caribbean disappeared rapidly after contact with the Europeans and was completely or nearly wiped out by the time permanent colonial settlements-often Spanishwere established (Hurwitz and Hurwitz 1971; Newson 1976; Campbell 1988). Therefore, this project uses the lower estimates of the population at the time of colonialism, as these figures appear to be a more accurate estimate of the size of the indigenous population at the onset of formal colonialism.

${ }^{\mathrm{c}}$ Most data come from British Colonial Office $(1953,1955,1958)$ and Kuczynski $(1939,1948,1949$, 1953). A score of $0.1 \%$ was used as the minimum. Data were not found for Bangladesh, India, Myanmar, and Sudan, yet their score is almost certainly below $0.1 \%$.

for precolonial development and, as expected, has a strong and positive relationship with our estimate of precolonial development $(\rho=.71)$ and a moderate and negative relationship with level of British colonialism $(\rho=-.43)$. A useful statistical proxy for level of colonialism is the percentage of the total population that is European at the end of the colonial period. This statistical proxy is negatively related to both precolonial population density and our measure of precolonial development $(-.75$ and -.60 , respectively). Thus, opposite from what we found for Spanish colonialism, the British tended to pursue higher levels of colonialism and settle more extensively in those precolonial regions with less people and less institutional complexity.

\section{THE EFFECTS OF COLONIAL INSTITUTIONS}

Recent literature shows that, as a generalization, the territories with relatively high levels of development before colonialism declined during and after the colonial period, whereas those with lower levels of precolonial development improved their relative position (Acemoglu et al. 2002). Our research suggests that-for economic development-the reversal took place roughly from 1750 to 1850 for the Spanish American colonies, the British settler colonies, and the British colonies in Asia. By contrast, the economic reversal occurred roughly from 1850 to 1950 for most of the British colonies in Africa and the West Indies. Here we account for these reversals in light of the institutions that the Spanish and British left behind, especially legal-administrative institutions that regulated com- 
merce and markets and that shaped the capacity of states and societal actors to implement developmental projects.

Although not acknowledged in the recent literature, there was in fact no great reversal for social development, given that the most politically complex and economically prosperous precolonial societies were not the most socially developed societies. Rather, the economically and politically developed precolonial societies usually simply remained as poor social performers throughout the colonial and postcolonial period, whereas the less economically and politically developed precolonial societies continued to be the better social performers. Here we show how Spanish and British colonial institutions-especially those regulating race and ethnicitycaused the persistence of these trajectories of social development.

\section{Spanish Colonialism and Economic Development}

During the 18th century, Bourbon monarchs implemented modernizing reforms in Spanish America that helped trigger the reversal of levels of economic development (Andrien 2001; Cotler 1978; Guardino and Walker 1992). After the War of the Spanish Succession (1700-1713), the Bourbon rulers began to allow European allies intermittent access to trade in the New World. By the end of this century, they introduced free trade in most parts of the empire and reduced tariffs and fees obstructing trade between the colonies and the Spanish mainland. These Bourbon reforms and technological improvements in shipping stimulated a dramatic increase in export production within the colonies.

However, the contrasting levels of mercantilist colonialism in the region differentially prepared territories to capitalize on the new trade opportunities. Territories that experienced high levels of colonialism during the 16 th and 17 th centuries were unable to respond effectively. In these colonial centers, powerful merchant guilds, or consulados, exercised a monopoly over trade during the late colonial and early independence periods. The individuals who controlled these guilds used their position to underpay producers, overcharge consumers, and stifle market competition (Brading 1971; Kicza 1983). While such practices enriched a select group of economic elites, they provided little basis for the kind of investment needed to stimulate growth in the more competitive markets of the 18th and early 19th centuries. Likewise, colonial restrictions on trade and the transport of goods were specifically designed to assist mineral-rich and populous colonial centers at the expense of peripheral regions in the empire. Once the Bourbons relaxed trade restrictions and allowed for greater movement of goods, the previously protected economic elites of the colonial centers could not compete in an open market.

To make matters worse, Spain installed state institutions in these regions 
primarily to oversee economic extraction and not to promote local development among the settler community. The consequence was that, as wealth increasingly came to depend on facilitating export production and stimulating local industries, state actors could not easily switch from extraction to capitalism. While the Bourbon Reforms improved the bureaucratic functioning of colonial state organizations, over the long run the states in the colonial centers continued to lack clear rules for governing internal positions and an enforcement system for punishing abuses among political officials and colonial settlers. As a result, state officials often simply pursued individual gains through rent seeking, which further undercut the establishment of a functioning rule of law accessible to broad sectors of society.

The specific ways in which such mercantilist institutions contributed to economic decline varied from case to case. In Peru, for example, economic elites faced enormous pressure when Bourbon reformers opened Atlantic ports and reorganized the political boundaries of the colonial empire. Colonial and postindependence state leaders proved unable to initiate even the most basic reforms to enhance profitability and induce competition in the mining sector. As a consequence, silver mining remained dominated by undercapitalized small-scale operations, and Peru declined rapidly alongside dwindling revenue collection in the mid-18th century. In Ecuador, merchant elites oversaw public monopolies that controlled what was a flourishing wool economy. Yet, with free-trade reforms, these elites were unable to adjust and compete with foreign textiles, which soon came to dominate the Andean market. Moreover, the state failed to reinvest resources from the wool industry into other potentially profitable sectors (Andrien 1995). At the time of independence, therefore, Ecuador was among the poorest countries in Latin America. Even Mexico began to experience the long-term negative effects of relying on a monopolistic mineral-based economy when its economy went into sharp decline in the late colonial and early independence periods (Coatsworth 1998; Fisher 1985; Jacobsen and Puhle 1986). Economic historians explain this failure by pointing to factors such as the inability of the Mexican state to pursue the creation of capital markets (Haber 1997) and the reluctance of politically powerful landed elites and mineral interests to embrace capitalist investment fully (Hansen 1971).

The trajectory of development was quite distinct for peripheral regions such as Argentina, Chile, Uruguay, and Venezuela. Although some cases were exceptions (e.g., Honduras), economic elites and state organizations developed in a more liberal direction in the peripheries of the Spanish empire than in its centers (Mahoney 2003). These areas usually did not see the development of state protections comparable to the consulados in Lima and Mexico City, and therefore faced stiffer competition from legal 
American Journal of Sociology

rivals and contraband (Halperín Donghi 1985). In many cases, the peripheral areas saw the emergence of coherent state organizations only with the onset of the Bourbon reforms and the creation of new administrative units in the empire. The new states tended to be controlled by economic elites whose power was grounded in the international trade of agricultural exports, such as coffee, sugar, and livestock products. In fact, elites in these areas often opposed mercantilist institutions that interfered with the movement of commerce and actively mobilized for the opening of markets (Halperín Donghi 1985; Lynch 1958; Knight 2001). It is important to note, however, that the new state institutions in the peripheral areas lacked the efficient internal structure and dense ties to societal groups necessary for broad-based development (Evans 1995). As a result, no area in Spanish America was institutionally prepared to rise to and remain at the top of the world hierarchy in development.

With the Bourbon reforms, nevertheless, the peripheral territories with powerful liberal elites were poised to experience significant economic growth driven by exports in expanding colonial and European markets (Burkholder and Johnson 1998). For instance, Venezuela developed through the export of cacao to Mexico and Spain (McKinley 1985). Likewise, Argentina and Uruguay experienced huge increases in the production of wheat and livestock (Rock 1987). Indeed, by the early 19th century, these two countries were among the richest nations in the non-European world, largely because of the profits deriving from these key export sectors. Even landlocked Paraguay witnessed substantial economic growth induced by the export of yerba (Whigham 1991). Development in Chile and Costa Rica had been stifled by Peru and Guatemala, respectively, throughout the colonial period. However, at independence these former colonial backwaters experienced rapid growth, with Chile gaining prosperity through mineral and wheat exports, and Costa Rica rising up via the production of coffee. While the wars of independence inflicted political turmoil and economic stagnation across all of Spanish America, the former colonial peripheries recovered faster when compared to the colonial centers (Coatsworth 1998). By 1850, many of the former colonial backwaters again witnessed expanding exports and increasing public revenues. Thus, the former colonial peripheries became the primary beneficiaries of the gradual incorporation of 19th-century Spanish America into the world economy. They did so not because of mercantilist institutions created by Spanish colonizers, but because these institutions were largely absent.

Spanish Colonialism and Social Development

Economic and sociocultural institutions designed to exploit and oppress indigenous people strongly shaped colonial and postcolonial trajectories 
of social development in Spanish America. On the one hand, these institutions were critical because they ensured that indigenous people themselves would experience low levels of social development. In turn, this reality made it much more difficult for countries with large indigenous populations (e.g., Mexico, Peru, Bolivia, Ecuador, and Guatemala) to achieve high levels of social development. On the other hand, institutions regulating indigenous people were consequential because they affected the proclivity and capacity of colonial and postcolonial states to pursue social welfare development more generally throughout society. In particular, state authorities in peripheral Spanish colonies with very small indigenous populations (e.g., Argentina, Costa Rica, and Uruguay) were more willing and able to build infrastructure and create public goods that benefited all citizens.

Spanish institutions had almost uniformly negative consequences for the indigenous populations in the colonies, but the specific nature of these consequences varied across territories with greater and lesser levels of colonialism. In the most central and populated areas of the colonial empire, major institutions were fundamentally designed to exploit indigenous labor; the Spanish pursued institutional development precisely to appropriate the fruits of indigenous labor and thereby enhance their own material well-being. For example, in Mexico, the infamous encomienda legally entitled Spanish elites to temporary labor services from a designated number of Indians, while in Peru the mita obligated the male indigenous population to work in agriculture, textile industries, and especially the mines for a specified period. Likewise, colonial jurisdictions maintained ethnoracial hierarchies betweens Indians and Spaniards and legally imposed heavy taxes on the indigenous population, which became a key source of state revenue in the colonial centers (Cole 1985; Florescano 1975; Mörner 1985; Spalding 1970; Stern 1993).

Outside the center areas, the Spanish also created institutions to extract surplus from indigenous people, but the precolonial societies here often had no formal tribute systems and thus were much more difficult to exploit. Furthermore, once diseases and conquest took their toll, the indigenous populations were often scattered or small in these areas (Newson 1985). As a result, many of the most important colonial institutions in the peripheries evolved into instruments designed simply to oppress the indigenous population, either by trying to turn them into docile Christian subjects or, increasingly, by simply eliminating them (on the distinction between exploitation and oppression, see Wright [1997]). For example, many of the most successful Jesuit missions in the New World were found in the more marginal colonial territories. Likewise, it was in the colonial peripheries where military leaders engaged in outright extermination campaigns against indigenous people (Halperín Donghi 1993; MacLeod 1984). 
American Journal of Sociology

By contrast, in the colonial centers, where elites relied on indigenous labor for their material well-being, the complete elimination of the indigenous population was never the goal.

In addition to differences in the relative importance of exploitation versus oppression, territories with varying levels of colonialism also of course differed in the size of their indigenous populations. In fact, relative size differentials among the territories with alternative levels of colonialism were reinforced over time, such that by the 19th and 20th centuries the former colonial peripheries sometimes had few or almost no indigenous people, whereas the former colonial centers still concentrated hundreds of thousands or even millions of indigenous people (Mahoney and vom Hau 2003). Because Spanish exploitation and oppression everywhere made the indigenous population a grossly impoverished subsection of society, these size differentials had obvious and major effects on levels of social development in the region, almost ensuring that areas with a sparse indigenous population would be the most socially developed parts of Spanish America (Psacharopoulos and Patrinos 1994; Mahoney 2003).

The varying degrees of colonial exploitation and the differences in the size of the indigenous population also affected state orientations toward the provision of public goods and the promotion of human welfare. The center territories of the Spanish empire were extremely unequal societies, with a strict spatial and cultural separation between concentrated and impoverished indigenous communities in the rural areas and more affluent Spanish and mestizo communities in the urban areas. In the wealthy cities of the center regions, the Spanish population had access to doctors, hospitals, schools, and even sometimes universities by the late colonial period (Haring 1947; Castañeda 1990). However, the vast majority of the overall population-usually indigenous people-lived in the countryside, and social and health services were not available here (Socolow 1996). Indeed, the various economic and sociocultural boundaries separating indigenous and nonindigenous groups, ultimately founded in exploitative colonial institutions, prohibited the possibility of these two groups sharing specialized knowledge with one another. Moreover, reigning economic rationale and widespread ethnoracism ensured that postcolonial state authorities would largely abstain from sponsoring investment in education or administering social services in the countryside.

By contrast, social development gradually improved in the more marginal Spanish territories of the colonial periphery. In these areas, ethnoracial distinctions became less prevalent, Europeans and mestizos emerged as the largest part of the population, and social mobility was more common (Zulawski 1990; Lockhart and Schwartz 1983). With the onset of the Bourbon Reforms and increased economic growth in these peripheral territories, the social infrastructure also improved. State authorities in- 
vested in water supply and basic health care. Likewise, the continued inflow of relatively educated immigrants from Spain and elsewhere in Europe (Mörner 1976) had a positive effect on the social development of the overall population. ${ }^{12}$

During the 19th century, the newly independent states of Spanish America formally rejected the ethnoracial hierarchies of the colonial period and aspired to integrate the different social and ethnic groups into national communities imagined as liberal and egalitarian. Throughout the region, state investments in health and education increased considerably (Halperín Donghi 1985; Safford 1985). Yet, these advances occurred least dramatically in the countries with a dense indigenous population, such as Ecuador, Guatemala, Peru, and Bolivia. Furthermore, especially in the former colonial centers, postcolonial state elites pursued the privatization of communal lands held by indigenous communities. These reforms eroded rural solidarity and kinship networks, fostered land scarcity in the countryside, and increased rural-to-urban migration-all of which had very negative consequences for social development.

By contrast, countries with a sparse indigenous population saw less disruptive processes of agrarian commercialization. Moreover, the liberal elites of former colonial peripheries viewed the high levels of European migration in their countries as signs of progress and civilization, emboldening them to pursue more inclusive social policies. In the late 19th and early 20th centuries, Argentina, Uruguay, and Costa Rica became regional pioneers in extending public education and state infrastructure to rural areas. In Uruguay and Costa Rica, in particular, state leaders implemented significant social welfare reforms in the first half of the 20th century. Thus, the distinct trajectories of social development in former colonial centers and former colonial peripheries were significantly grounded in contrasting Spanish modes of controlling indigenous people. In central areas with a dense indigenous population, intense exploitation and the creation of stark ethnoracial boundaries during the colonial period ensured low levels of social development among indigenous people over the long run and reduced state elites' commitment to the creation of public goods in the postcolonial period. By contrast, in the more marginal territories where smaller indigenous populations were harshly oppressed but less systematically exploited, future state leaders were confronted with fewer institutional obstacles hindering the promotion of social welfare among the mostly European and mestizo population that remained.

${ }^{12}$ As a countervailing trend, however, the migration of slaves from Africa, many of whom formed part of the labor force in the peripheral colonies, decreased the level of social development in these areas. Between 1701 and 1810, some 578,600 African slaves were imported to Spanish America (Curtin 1969, pp. 116-19). 
American Journal of Sociology

British Colonialism and Economic Development

When the British heavily settled a region, they tended to create institutions-especially legal codes to coordinate markets and bureaucraciesthat were favorable to economic development. By contrast, when the British did not heavily settle an area, they tended to impose few institutions to regulate the economy and state, and those that they did impose often had adverse consequences for development. As a result, some former British colonies are among the richest countries in the world, whereas others are among the poorest.

In the United States, Canada, Australia, and New Zealand, British colonialism laid the basis for future economic prosperity by leaving behind a functioning legal system that could sustain capitalist development. Effective court systems and local policing institutions that enforced contracts underpinned the stable property rights emphasized by economic historians (e.g., North 1990). A classic example is the powerful county courts of New England, whose judges were in the position to respond in broadly impersonal ways to property conflicts and contract fraud, and who could enforce juridical decisions through professional law officers (Cook 1976; Knöbl 1998). More generally throughout the settler colonies, the commonlaw system protected colonists from arbitrary state action and provided a barrier to the instrumental use of colonial government for the enrichment of elite segments. ${ }^{13}$

The land policies of the British crown also reflected the authority of the colonial state over elite interests. In the settler colonies, the respective local bodies of the colonial state were regarded as the principal owners of land. The state carefully controlled land distribution and the pace of settlement, including by regulating minimum and maximum acreages and by setting land prices. Land policies in turn reinforced the prevalence of smallholders and prevented the formation of powerful landed elites with the capacity to establish monopolistic structures harmful to long-run economic development. Moreover, the land policies in British settlement colonies facilitated economic transactions among farmers and planters (Adelman 1994; Coatsworth 1993; Solberg 1987). For instance, smallholder loans led to the creation of the first major banks and stock markets in the postcolonial period (e.g., Haber 1991).

British rule also had positive legacies in several directly ruled colonies. In Hong Kong and the Straits Settlements (Malacca, Penang, and Sin-

\footnotetext{
${ }^{13}$ Although the legal institutions did not support a rent-seeking landed elite, the courts were not completely unbiased. Horwitz (1977) finds that the American legal system systematically enforced the interests of business over farmers, workers, and consumers, thereby assisting capitalist expansion when obstacles were present. See also Bensel (1990) and Sanders (1999).
} 
gapore), for example, extensive legal institutions were created (Heussler 1981; Ngo 1999; Ryan 1976). In addition, these colonies were founded as free ports and therefore had tax and labor systems in place that helped each take advantage of their strategic trading location to become global economic centers (Huff 1994; Meyer 2000).

In colonies with plantation systems, however, the legacy of direct British rule was less straightforward because of the presence of powerful elites who had the potential to capture state institutions and obstruct free markets. Although common-law institutions and representative assemblies were created in the plantation colonies, the landed European elite were able to exert considerable control over these institutions until the 1940s and thereby protect plantation interests at the expense of others. In the colonial American South, for instance, the legislative assemblies and legal systems were dominated by plantation owners. Likewise, in order to maintain control over a large and cheap labor force, West Indies planters during the postemancipation era were able to pressure the colonial administration to implement legislation that prevented former slaves from buying or successfully managing their lands (Adamson 1972; Beckford 1983; Young 1958). In turn, elite domination of the state and society limited economic diversification and dynamism (Beckford 1983; Ferleger 1985; Mandle 1974).

While settler colonialism and direct colonialism established state institutions conducive to economic growth, and while plantation colonies featured forms of direct rule with less beneficial consequences, the indirectly ruled colonies of Britain unambiguously displayed institutions not conducive to economic development. In many African colonies, the British did not engage in either the establishment of a functioning rule of law or the creation of an effective administration. In addition, the implementation of indirect rule enhanced the power of indigenous elites to use colonial taxation systems and control of customary law for personal enrichment. As a consequence, patrimonial and fragmented states emerged throughout British Africa (Mamdani 1996; Boone 1994; Migdal 1988; Lange 2004). The construction of agricultural monopsonies via marketing boards also allowed state officials and other elites to gain huge rents by underpaying peasants for their produce; this, in turn, promoted an unproductive economic elite, weak peasant production, and the preeminence of dysfunctional markets (Bates 1981). The institutions of indirect rule thus amounted to a formula for economic disaster.

In India, hybrid colonialism also allowed elite intermediaries to strengthen their control of land and labor and thereby obstruct free economic production (Edwardes 1967; Kumar 1989). In the indirectly ruled areas, the British guaranteed protection to oppressive local elites, who otherwise likely would have faced major rebellions from rural producers 
American Journal of Sociology

(Kulkarni 1964). In the directly ruled areas, officials employed indigenous elites for a number of activities because of the general absence of the colonial administration, especially in the rural areas (Gopal 1963). In many instances, local elites were also given rights to large tracts of land and were thereby able to control villages technically under British administration (Kumar 1989). The concentration of these duties and powers in elite hands, in turn, made possible the hyperexploitation of the peasantry, something that appears to have caused lower agricultural production and investment in public goods even after the end of colonialism (Banerjee and Iyer 2005).

Although similar in some ways, India's hybrid colonialism differed from indirect colonialism. In particular, the central administration in colonial India was larger and more bureaucratically organized than its counterpart in indirectly ruled colonies (Kohli 2004). As a result, in postcolonial India, the central state could sometimes act more corporately and effectively in policy implementation, especially when state action did not require complex linkages with societal groups. For instance, the Indian state had important successes in promoting information technology industries, an outcome that required neither active state intervention at the local level nor the transformation of local power relations (Evans 1995).

The colonial institutions of other hybrid colonies similarly left a mixed economic legacy. Malaysia, for example, had extremely powerful legaladministrative institutions in parts of the Malaya Peninsula; yet these institutions were much weaker in Sarawak, North Borneo, and the Unfederated Malay States, where the British imposed different forms of indirect rule (Brown and Ampalavanar 1986; Emerson 1937; Heussler 1981; Zawawi 1998). Consequently, economic development has been mostly limited to formerly directly ruled areas on the Malay Peninsula, even though state efforts to promote industrialization during the postcolonial period were generally quite successful (Harper 1999; Jomo 1993). In South Africa, segmented economies and divided legal-administrative institutions were also present, but these patterns came about because of racial segregation, not because of the amalgamation of colonial regions with different forms of colonial rule (Mamdani 1996; Marx 1998). Here the white territories featured effective legal-administrative institutions and a superb economic infrastructure, while the black areas were neglected and under the control of powerful chiefs who collaborated with the apartheid regime. Thus, economic development has been regionalized in Malaysia and racialized in South Africa.

In sum, the British colonies that experienced the greatest colonial institutional transfer - the United States, Canada, Australia, New Zealand, Hong Kong, and Singapore-saw the establishment of a rule of law and functioning markets, while the parts of the British Empire that had the 
least colonial influence-extractive colonies in sub-Saharan Africa and South Asia-exhibited institutions that were impediments to growth in a capitalistic world economy. Alternatively, the colonies that experienced an intermediate level of colonial influence-mainly the plantation colonies and the areas with hybrid forms of colonialism-were left with a mixed economic legacy.

\section{British Colonialism and Social Development}

In the colonies with high levels of colonial influence, market institutions not only ensured future economic prosperity but also set the stage for improved social performance. For instance, in the late-19th-century United States, rapid economic growth and industrialization promoted investment in primary education and enhanced the population's social wellbeing through nutrition and basic health care. By the late 19th century, Australia also had achieved decades of vigorous economic growth, which coincided with increasing labor mobilization and substantial investments in social facilities (Denoon and Mein-Smith 2000; Pike 1970). By contrast, former British colonies in sub-Saharan Africa and India did not witness periods of sustained economic development and therefore did not experience the beneficial spillover effects of long-term economic prosperity on social development. ${ }^{14}$

In addition, the legal-administrative institutions of British colonies directly affected the capacity of the state to provide public goods such as education, health care, sanitation, and poverty relief-all of which had their own reciprocal spillover effects on economic development. In the United States, these capacities were developed largely after the War of Independence. In most other colonies, state provision of public goods began during the colonial period, often in response to political mobilization by indigenous groups. For example, pressures for social investment began to mount during the Depression and escalated even further after World War II, resulting in changes in colonial policy that earmarked at least some funds for welfare development (Goldsworthy 1971; Lee 1967).

The extent of social development that was actually achieved, however, depended on the available state infrastructure (Lange 2004). In cases of direct colonialism, large and bureaucratically organized state apparatuses made possible the provision of numerous public goods. Alternatively, in indirectly ruled territories, colonial rule left ineffective administrations, and the general incapacity of the colonial states obstructed postwar social

${ }^{14}$ An important empirical exception to this argument is the state of Kerala in India. As this case illustrates, better overall social performance can be achieved even in the absence of sustained economic growth (Drèze and Sen 1989; Heller 1999). 
American Journal of Sociology

development, leaving several British colonies with some of the lowest education rates and life expectancies in the world.

Legal-administrative institutions also indirectly affected social development by shaping the ability of individuals to pursue their own wellbeing. In directly ruled Ceylon and Mauritius, for example, legal protections against elite interests helped create vibrant communities of small landholders, and these communities formed movements that successfully pressured state officials to extend social welfare policy during the late colonial and postcolonial periods (de Silva 1997; Jeffries 1962; Lange 2003; Nyrop et al. 1971). In colonial India and sub-Saharan Africa, however, peasants did not have access to impartial legal institutions, and the predominance of hierarchical and dependent relationships created an environment antithetical to social mobilization (Mamdani 1996; Migdal 1988). Subordinate groups were therefore unable to form movements in support of their well-being.

Colonial legacies of ethnoracial discrimination and exploitation had their own crucial effects on social development for all types of British colonies. Social stratification systems and labor-coercive institutions installed by British colonizers contributed to enduring ethnoracial polarization. In particular, they prevented large groups from being able to participate in productive economic opportunities, stifled the formation of labor associations, and often fueled violent ethnic-based conflict (Beckford 1983; Marx 1998). Indeed, even in the presence of economic prosperity, staunch ethnoracial cleavages made it nearly impossible for countries to achieve high national levels of literacy, life expectancy, and education (Alesina, Baqir, and Easterly 1999; Filmer and Pritchett 1999; McGuire 2001).

In the American South, British colonists pursued labor-intensive agriculture and justified the enslavement of black people on the basis of racial ideologies (Marx 1998). In Australia, racist policies deprived Aborigines of their tribal lands and excluded them from legally encoded rights (Denoon and Mein-Smith 2000; Spillman 1996). Ever since, AfricanAmericans and Aborigines have performed poorly on social development indicators. In plantation colonies, the institutional legacies of slavery caused the racialization of nearly all social institutions. The importation of hundreds of thousands of South Asian indentured workers and colonial policies designed to separate them from either former slaves or indigenous inhabitants through a race-based, divide-and-rule strategy promoted ethnic conflict in Fiji, Guyana, and Sri Lanka. In South Africa, British colonizers pioneered spatial segregation between blacks and whites; intrawhite conflict between the British and the Dutch further entrenched ideas about white superiority in institutions and culture, paving the way for the implementation of apartheid (Marx 1998). 
The colonies with low levels of colonial influence were also afflicted by ethnoracial conflict. In colonial India, British institutions reinforced distinctions based on caste and religion. For instance, the Indian army carefully segregated on the basis of religion and caste membership (Bayly 1988; Metcalf and Metcalf 2002). Such policies promoted social inequalities and increased sectarian conflict, the latter of which led to millions of deaths during the partition of India and Pakistan. In Myanmar, the British pitted the Burmese against the minority ethnic groups in order to control the territory more easily, a policy that created distinct institutions in both areas and set the stage for the country's postcolonial civil war (Smith 1999). A similar ethnically bifurcated form of rule in the Sudandividing the Muslim north from the Christian and Animist south-likewise promoted extreme violence and human misery (Morrison 1971; Woodward 1990).

Even when not inciting conflict through a divide-and-rule strategy, low levels of British colonialism polarized society through the construction of politicized ethnoracial identities and patron-client systems (Laitin 1986; Stoler and Cooper 1997; Vail 1989). Throughout sub-Saharan Africa, for example, the colonial administration channeled resources through the chiefs, who in turn passed them on to key supporters in order to maintain their positions. These patron-client relations generated politicized ethnoracial identities because common cultural heritage was the main source of chiefdom legitimacy and because the provisioning of communal goods to local subjects-especially land - tied one's ethnoracial identity to material payoffs (Mamdani 1996). Moreover, given scarce resources and competition over the postcolonial state, the chiefs and other political entrepreneurs often appealed to ethnicity for support and mobilization, thereby embedding the postcolonial state in a polarized civil society.

Thus, social development in former British colonies has been shaped by colonial legacies in three primary ways: economic performance, state and societal capacities to promote social welfare development, and ethnoracial polarization. While the first two were positively related to the intensity of British colonialism, the third afflicted a number of British colonies regardless of the level of colonial influence. More intensive British colonialism was therefore better for social development in general, although ethnoracial stratification propelled by the colonizers often contributed to pervasive social inequalities and violence in a wide variety of former British colonies, with ultimately harmful consequences for social development. 
American Journal of Sociology

Postcolonial Development Trajectories

Finally, to return to the overall comparison, simple descriptive statistics can be used to illustrate the differing effects of levels of Spanish and British colonialism on long-run development. In table 4, we compare our estimates of levels of colonialism and precolonial development to a statistical indicator of postcolonial development derived from the Human Development Index (HDI). The HDI measures national development by aggregating data on life expectancy at birth, adult literacy, gross primary school enrollment ratios, and GDP per capita (United Nations 2002). For illustrative purposes, we focus on only two points in time-1975 and 2000 - though our findings apply to any two periods for which HDI data are available. ${ }^{15}$

We first assess the correlation between level of colonialism and HDI. For the Spanish colonies, the coefficients are -.59 and -.48 for HDI 1975 and HDI 2000, respectively. The outliers are peripheral Spanish colonies that did not experience substantial development, especially Nicaragua and Paraguay. In addition, Mexico performed above average despite the fact that it was a central colony. These cases lead the relationship to be less than perfect, but even when they are included, level of colonialism remains clearly and negatively associated with postcolonial development. Conversely, for the British colonies, level of colonialism is positively associated with postcolonial development, and the correlations are very strong: .86 and .88 for HDI 1975 and 2000, respectively.

Next, we correlate precolonial and postcolonial levels of development. Consistent with the argument that colonialism caused a great reversal in all regions, we find that our ordinal estimate of precolonial development is negatively related to the HDI indices. For the Spanish colonies, the precolonial/postcolonial coefficients are -.63 for HDI 1975 and -.58 for HDI 2000. For the British colonies, the precolonial/postcolonial coefficients are -.61 and -.41 , respectively. Though these numerical data by themselves can hardly make the case for our theory of colonialism, they do provide additional support on top of our comparative-historical analysis of particular cases.

\section{CONCLUDING DISCUSSION}

This analysis speaks to one of the fundamental questions of macrosociology: What explains differences in levels of development in the nonEuropean world? We follow recent work in arguing that colonialism was

${ }^{15}$ The correlation between HDI 1975 and HDI 2000 is .96 for the Spanish colonies and .93 for the British colonies. 
TABLE 4

Trajectories of Development: Spanish and British Colonies

\begin{tabular}{|c|c|c|c|c|}
\hline Country & $\begin{array}{c}\text { Level of } \\
\text { Precolonial } \\
\text { Development }\end{array}$ & $\begin{array}{c}\text { Level of } \\
\text { Colonialism }\end{array}$ & HDI (1975) & HDI (2000) \\
\hline \multicolumn{5}{|l|}{ Spanish colonies: } \\
\hline Argentina ..... & Low & Low & .79 & .84 \\
\hline Bolivia ........... & High & High & .51 & .65 \\
\hline Chile $\ldots \ldots \ldots \ldots \ldots \ldots$ & Low & Low & .70 & .83 \\
\hline Colombia .... & Intermediate & Intermediate & .66 & .77 \\
\hline Costa Rica .............. & Low & Low & .75 & .82 \\
\hline Cuba & Low & Intermediate & & .80 \\
\hline Dominican Republic ... & Low & Intermediate & .62 & .73 \\
\hline Ecuador ............... & High & High & .62 & .73 \\
\hline El Salvador $\ldots \ldots \ldots \ldots$ & Intermediate & Intermediate & .59 & .71 \\
\hline Guatemala $\ldots . . . . . . . . .$. & High & High & .51 & .63 \\
\hline Honduras $\ldots \ldots \ldots \ldots . . . .$. & Intermediate & Intermediate & .52 & .64 \\
\hline Mexico ......... & High & High & .69 & .80 \\
\hline Nicaragua ..... & Intermediate & Low & .57 & .64 \\
\hline Panama ........ & Low & Low & .71 & .79 \\
\hline Paraguay ......... & Low & Low & .67 & .74 \\
\hline Peru $\ldots . . . . .$. & High & High & .64 & .75 \\
\hline Uruguay $\ldots . .$. & Low & Low & .76 & .83 \\
\hline Venezuela & Intermediate & Intermediate & .72 & .77 \\
\hline \multicolumn{5}{|l|}{ British colonies: } \\
\hline Australia ..... & Low & High & .84 & .94 \\
\hline Bahamas ..... & Low & Intermediate & & .83 \\
\hline Bangladesh ... & High & Low-intermediate & .34 & .48 \\
\hline Barbados ................ & Low & Intermediate & & .87 \\
\hline Belize ............ & Low & Intermediate & & .78 \\
\hline Botswana ....... & Intermediate & Low & .49 & .57 \\
\hline Brunei................ & High & Intermediate & & .86 \\
\hline Canada ......... & Low & High & .87 & .94 \\
\hline Cyprus & High & Intermediate-high & & .88 \\
\hline Egypt . & High & Low-intermediate & .44 & .64 \\
\hline Fiji & Intermediate & Low-intermediate & .66 & .76 \\
\hline Gambia $\ldots \ldots \ldots \ldots \ldots$ & Intermediate & Low & .27 & .41 \\
\hline Ghana ................... & High & Low & .44 & .55 \\
\hline Guyana $\ldots \ldots \ldots \ldots \ldots$ & Low & Intermediate & .68 & .71 \\
\hline Hong Kong ............. & High & Intermediate-high & .76 & .89 \\
\hline India $\ldots \ldots \ldots \ldots \ldots \ldots$ & High & Low-intermediate & .41 & .58 \\
\hline Jamaica ................ & Low & Intermediate & .69 & .74 \\
\hline Kenya $\ldots \ldots \ldots \ldots \ldots$ & Low & Low-intermediate & .44 & .51 \\
\hline Lesotho ................. & Intermediate & Low & .48 & .54 \\
\hline Malawi .................. & Intermediate & Low & .32 & .40 \\
\hline Malaysia ......... & Intermediate & Intermediate & .62 & .78 \\
\hline Mauritius ..... & Low & Intermediate & .63 & .77 \\
\hline Myanmar & High & Low-intermediate & & .55 \\
\hline New Zealand ............ & Low & High & .85 & .92 \\
\hline Nigeria $\ldots \ldots \ldots \ldots \ldots$ & High & Low & .33 & .46 \\
\hline
\end{tabular}


American Journal of Sociology

TABLE 4 (Continued)

\begin{tabular}{|c|c|c|c|c|}
\hline Country & $\begin{array}{c}\text { Level of } \\
\text { Precolonial } \\
\text { Development }\end{array}$ & $\begin{array}{c}\text { Level of } \\
\text { Colonialism }\end{array}$ & HDI (1975) & HDI (2000) \\
\hline Pakistan & High & Low-intermediate & .35 & .50 \\
\hline Sierra Leone ............. & Intermediate & Low & & .28 \\
\hline Singapore & Low & Intermediate-high & .72 & .89 \\
\hline Solomon Islands ........ & Low & Low & & .62 \\
\hline South Africa ............ & Intermediate & Intermediate-high & .65 & .70 \\
\hline Sri Lanka ............... & High & Intermediate & .62 & .74 \\
\hline Sudan $\ldots \ldots \ldots \ldots \ldots . . . . . .$. & High & Low & .35 & .50 \\
\hline Swaziland .............. & Intermediate & Low & .51 & .58 \\
\hline Tanzania . & Intermediate & Low & & .44 \\
\hline Trinidad/Tobago ....... & Low & Intermediate & .72 & .81 \\
\hline Uganda ........ & High & Low & & .44 \\
\hline United States ........... & Low & High & .86 & .94 \\
\hline Zambia .................. & Intermediate & Low & .45 & .43 \\
\hline Zimbabwe $\ldots \ldots \ldots \ldots$ & High & Low-intermediate & .55 & .55 \\
\hline
\end{tabular}

NotE. - Human Development Index (HDI) scores are from United Nations (2002). Level of precolonial development and level of colonialism are from tables 2 and 3 above.

of decisive importance, triggering a reversal of fortunes in which more economically developed precolonial territories became less developed, and less economically developed areas became more developed. However, whereas the recent literature emphasizes domestic conditions in the colonies and insists that "it is not the identity of the colonizer . . . that matters" (Acemoglu et al. 2001, p. 1373; see also Robinson and Sokoloff 2003 , p. 174), we argue that one must simultaneously pay attention to conditions in precolonial territories and the identity of the colonizer to understand adequately how colonialism shaped long-run development.

Our argument specifically shows that the historical processes through which colonial institutions were installed and shaped subsequent development differed dramatically for Spanish and British colonialism (see fig. 2). Spain colonized most heavily precolonial regions that were prosperous because these areas offered the greatest potential for accumulation under a mercantilist economic model. By contrast, Britain colonized most heavily precolonial regions that were less complex because these areas offered the greatest potential for capitalist accumulation. In turn, areas that were heavily colonized by Spain saw the introduction of substantial mercantilist institutions, and these institutions became important impediments to postcolonial development. Areas that were heavily colonized by Britain saw the introduction of substantial liberal institutions, and these institutions were positively associated with development. Hence, both Spanish and British colonialism reversed the fortunes of precolonial regions, but they did so in very different ways. 
a. Mercantilist Colonialism: Spain

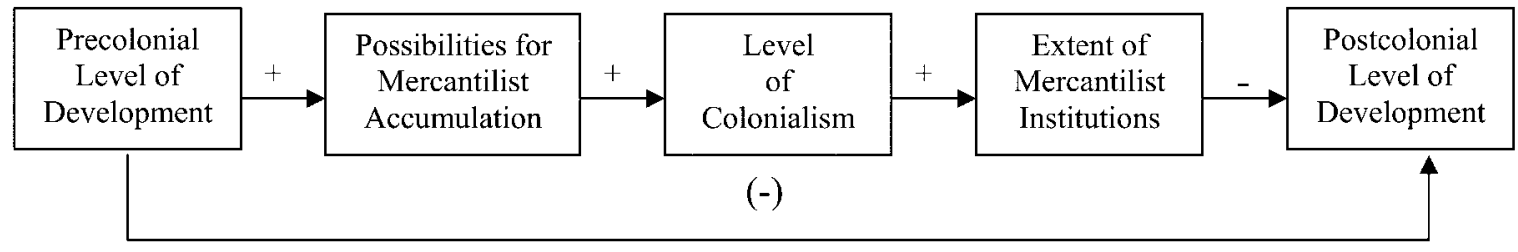

b. Liberal Colonialism: Britain

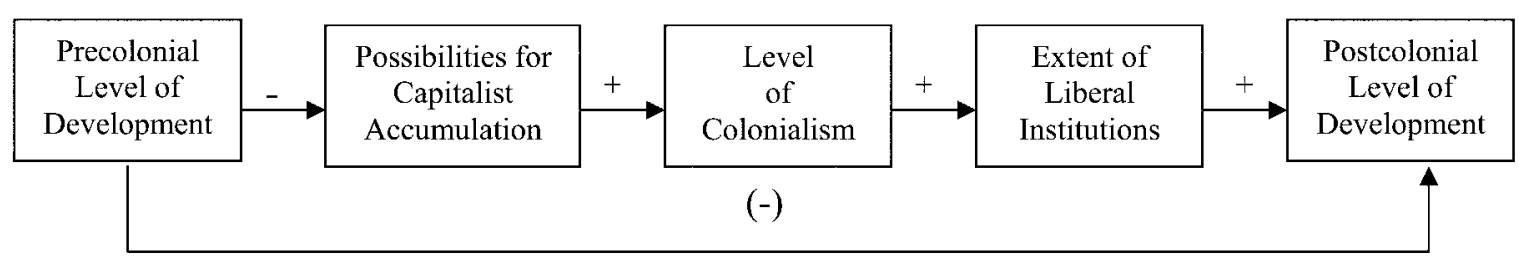

FIG. 2.-Elaborated model of colonialism and development 
American Journal of Sociology

The theory of colonialism that informs this argument-rooted in the distinction between mercantilist and liberal colonizers-offers new insights into debates about colonialism. Concerning the onset of colonialism, the theory sheds light on the relative importance of three sets of domestic conditions: population size, disease environment, and natural resource endowment. For population size, we show that mercantilist colonizers preferred to settle highly populated areas because of their substantial labor pools, whereas liberal colonizers avoided settlement in densely settled areas because the radical displacement of the indigenous population was seen as too costly. Our finding is inconsistent with the work of Acemoglu et al. (2001, 2002), who assume that population size is negatively associated with colonial settlement across all European occupiers. However, it is consistent with previous qualitative comparative work on colonialism (e.g., Fieldhouse 1966).

In terms of disease environment, our evidence does not challenge the basic insight that all colonial powers ceteris paribus preferred to inhabit low-mortality environments. However, we show that this basic preference could easily be outweighed by other strategic calculations. Mercantilist Spain permanently settled in areas with high mortality rates because mineral wealth was located there, and even the British initially were drawn to high-mortality plantation colonies in the New World (Engerman and Sokoloff 2002, p. 51). Hence, we caution against asserting that disease environment was a critical factor influencing settlement patterns before liberalism as an economic model had fully taken hold. Instead, in the mercantilist era of colonialism, disease environment was a relatively minor consideration.

As for natural resource endowments, the presence of precious metals was decisive in fostering heavy mercantilist occupation, as can be seen by Spanish settlement in Mexico and the Andes. Beyond this, somewhat higher levels of Spanish colonialism were also found in areas with climates and soils that allowed for specialization in a profitable export crop, such as sugar in the Caribbean. British colonialists similarly showed at least some preference for areas where precious metals were located (e.g., South Africa), ecological conditions allowed for profitable agriculture (e.g., the West Indies), or preexisting markets made possible profitable trade (e.g., Hong Kong). However, the most important British settlement colonies had soils and climates favorable not to export agriculture but rather to small-scale independent farms. These conditions were exactly what mercantilist Spain avoided. Hence, Engerman and Sokoloff (2002) are correct to highlight the importance of climate and soils for settlement patterns, but they do not provide a framework for understanding how these factors differentially influenced settlement across mercantilist and liberal powers.

Our analysis also offers new perspectives on the role of colonial insti- 
tutions in promoting development and underdevelopment. The literature on the colonial reversal largely treats these institutions as a "black box," though it strongly speculates about the importance of property rights (Acemoglu et al. 2002; Acemoglu 2002). Our analysis differs in its emphasis. For one thing, we put greater weight with colonial state institutions, especially those promoting the rule of law in the British colonies. We stress that the extent of colonial bureaucracy often drove the extent of property rights, and thus that the state rather than the market was the central mechanism linking British colonialism with development. As for the Spanish colonies, the issue was not so much the degree to which property rights were established, but rather the extent to which the colonial state had created actors and institutions that impeded the postcolonial creation of capitalist property rights. In some cases, the Spanish presence was marginal enough that postcolonial actors were able to build capitalist institutions without having to overcome entrenched mercantilist obstructions.

We find broad support for Engerman and Sokoloff's (2002) argument that colonial institutions fostering inequality had detrimental effects for long-run development. Likewise, we believe that Acemoglu et al.'s (2001) concern with the long-run damaging effects of extractive colonial institutions is well founded. However, we emphasize the different kinds of extractive and inequality-enhancing institutions that the Spanish and British established. Spanish extractive institutions, such as coercive labor systems, required a substantial colonial presence. By contrast, British extractive institutions, such as marketing boards, were generally implemented in conjunction with indirect colonialism and required only a limited colonial presence. Hence, we find it useful to distinguish the extractive institutions that accompanied colonialism by a mercantilist power and those that accompanied colonialism by a liberal power.

Our analysis of colonial legacies also varies from the recent work of economists in its emphasis on specifically ethnoracial stratification, which not only produces psychological hardship among subordinate groups, but also affects their access to markets, health, and educational opportunities. For the Spanish-American colonies, we view colonial exploitation of the indigenous population as a leading reason why countries with a dense indigenous population have long been the region's worst performers in the area of social development, whereas those without such a population have long been the region's most successful at achieving social development. For the British colonies, ethnoracial systems were also a decisive factor affecting social development. In the United States, Canada, Australia, and New Zealand, conquered peoples were uprooted and marginalized, but the remaining indigenous populations were usually so small that macrolevel statistics on social development do not capture this history 


\section{American Journal of Sociology}

of oppression. South Africa and Zimbabwe, on the other hand, had much larger indigenous populations. As a result, the effects are evident in aggregate data, and ethnoracial conflict has been widespread. In former plantation colonies, capital and labor were divided along racial lines, with Europeans owning and Africans and Asians working, causing these societies to be racially stratified and to experience long-term differentials in individual well-being based on the color of one's skin. In addition, the introduction of South Asian indentured workers in several plantation colonies almost always caused strife with either the indigenous population or with former slaves, conflict that has severely limited social development in former colonies such as Guyana, Sri Lanka, and Fiji. As these examples underscore, ethnoracial stratification and violence often was caused by British colonialism, affected colonies with diverse levels of colonial influence, and had very negative consequences for development.

More work surely needs to be done in identifying the specific role and relative weight of different colonial institutions for long-run development. As this research takes place, however, investigators would be wise to pay close attention to the identity of the colonial occupier, for different colonial powers pursued contrasting modes of institutional establishment, with major implications for postcolonial development.

\section{REFERENCES}

Abernethy, David B. 2000. The Dynamics of Global Dominance: European Overseas Empires, 1415-1980. New Haven, Conn.: Yale University Press.

Acemoglu, Daron. 2002. "Comment." Economia 3:94-102.

Acemoglu, Daron, Simon Johnson, and James A. Robinson. 2001. "The Colonial Origins of Comparative Development: An Empirical Investigation." American Economic Review 91:1369-1401.

. 2002. "Reversal of Fortune: Geography and Institutions in the Making of the Modern World Income Distribution.” Quarterly Journal of Economics 117:1231-94.

Adamson, Alan. 1972. Sugar without Slaves: The Political Economy of British Guiana, 1838-1904. New Haven, Conn.: Yale University Press.

Adcock, Robert, and David Collier. 2001. "Measurement Validity: A Shared Standard for Qualitative and Quantitative Research.” American Political Science Review 95: 529-46.

Adelman, Jeremy. 1994. Frontier Development: Land, Labour, and Capital on the Wheatlands of Argentina and Canada, 1890-1914. New York: Clarendon.

Ajayi, J. F. Ade, and Michael Crowder. 1971. History of West Africa. London: Longman.

Alam, M. Shahid. 1994. "Colonialism, Decolonisation and Growth Rates: Theory and Empirical Evidence." Cambridge Journal of Economics 18:235-57.

Alesina, Alberto, Reza Baqir, and William Easterly. 1999. "Public Goods and Ethnic Divisions." Quarterly Journal of Economics 114:1243-84.

Alpers, Edward A. 1975. Ivory and Slaves: Changing Pattern of International Trade in East Central Africa to the Later Nineteenth Century. Berkeley: University of California Press.

Andrien, Kenneth J. 1995. The Kingdom of Quito, 1690-1830: The State and Regional Development. Cambridge: Cambridge University Press. 


\section{Colonialism and Development}

- 2001. Andean Worlds: Indigenous History, Culture, and Consciousness under Spanish Rule, 1532-1825. Albuquerque: University of New Mexico Press.

Banerjee, Abhijtit, and Lakshmi Iyer. 2005. "History, Institutions and Economic Performance: The Legacy of Colonial Land Tenure Systems in India." American Economic Review 95:1190-1213.

Bates, Robert H. 1981. Markets and States in Tropical Africa: The Political Basis of Agricultural Policies. Berkeley and Los Angeles: University of California Press.

Bayly, C. A. 1988. The New Cambridge History of India: Indian Society and the Making of the British Empire. Cambridge: Cambridge University Press.

Beckford, George. 1983. Persistent Poverty: Underdevelopment in Plantation Economies of the Third World. London: Zed Books.

Bennett, Judith. 1987. Wealth of the Solomons: A History of a Pacific Archipelago, 1800-1978. Honolulu: University of Hawaii Press.

Bensel, Richard Franklin. 1990. Yankee Leviathan: The Origins of Central State Authority in America, 1858-1877. Cambridge: Cambridge University Press.

Bernhard, Michael, Christopher Reenock, and Timothy Nordstrom. 2004. "The Legacy of Western Overseas Colonialism on Democratic Survival." International Studies Quarterly 48:225-50.

Bertocchi, Graziella, and Fabio Canova. 2002. "Did Colonization Matter for Growth? An Empirical Exploration into the Historical Causes of Africa's Underdevelopment." European Economic Review 46:1851-71.

Boone, Catherine. 1994. "States and Ruling Classes in Postcolonial Africa: The Enduring Contradictions of Power." Pp. 108-40 in State Power and Social Forces: Domination and Transformation in the Third World, edited by Joel Migdal, Atul Kohli, and Vivienne Shue. New York: Cambridge University Press.

Bowman, Kirk, Fabrice Lehoucq, and James Mahoney. 2005. "Measuring Political Democracy: Case Expertise, Data Adequacy, and Central America." Comparative Political Studies 8:939-70.

Boyd-Bowman, Peter. 1976. "Patterns of Spanish Emigration to the Indies until 1600." Hispanic American Historical Review 56:580-604.

Brading, David A. 1971. Miners and Merchants in Bourbon Mexico, 1763-1810. Cambridge: Cambridge University Press.

British Colonial Office. 1953. Annual Colonial Report (Gold Coast). London: Her Majesty's Stationary Office.

- 1955. Annual Colonial Report (the Bahamas, Barbados, Basotholand, British Guiana, British Honduras, Ceyon, Fiji, Gambia, Hong Kong, Jamaica, Kenya, Malaya, Mauritius, North Borneo, Northern Rhodesia, Nyasaland, Sarawak, Sierra Leone, Singapore, Southern Rhodesia, Swaziland, Tanganyika, Trinidad and Tobago, Uganda, Zanzibar). London: Her Majesty's Stationary Office.

. 1958. Annual Colonial Report (Bechuanaland, the Solomon Islands). London: Her Majesty's Stationary Office.

Brown, Ian, and Rajeswary Ampalavanar. 1986. Malaysia. Denver: Clio.

Burkholder, Mark A., and Lyman L. Johnson. 1998. Colonial Latin America. New York: Oxford University Press.

Campbell, Mavis C. 1988. The Maroons of Jamaica, 1655-1796: A History of Resistance, Collaboration and Betrayal. Granby, Mass.: Bergin and Garvey.

Carrasco, Pedro. 1976. "La sociedad mexicana antes de la conquista." Pp. 165-288 in Historia general de México: Tomo I, edited by Daniel Cosío Villegas. Mexico City: El Colegio de México.

Castañeda, Carmen. 1990. "Student Migration to Colonial Urban Centers: Guadalajara and Lima." Pp. 128-42 in Migration in Colonial Spanish America, edited by David J. Robinson. Cambridge: Cambridge University Press.

Coatsworth, John H. 1993. "Notes on the Comparative Economic History of Latin America and the United States." Pp. 264-302 in Development and Underdevelopment 


\section{American Journal of Sociology}

in America: Contrasts of Economic Growth in North and Latin America in Historical Perspective, edited by Walther L. Bernecker and Hans Werner Tobler. Berlin: Walter de Gruyter.

- 1998. "Economic and Institutional Trajectories in Nineteenth-Century Latin America." Pp. 23-54 in Latin American and the World Economy since 1800, edited by John H. Coatsworth and Alan M. Taylor. Cambridge, Mass.: Harvard University, David Rockefeller Center for Latin America Studies.

Cole, Jeffrey A. 1985. The Potosi Mita, 1573-1700: Compulsory Labor in the Andes. Standford, Calif.: Stanford University Press.

Collins, Robert O., James McDonald Burns, and Erik Kristofer Ching, eds. 1994. Historical Problems of Imperial Africa. Princeton, N.J.: Markus Wiener.

Cook, Edward M. 1976. The Fathers of the Towns: Leadership and Community Structure in Eighteenth-Century New England. Baltimore: Johns Hopkins University Press.

Cotler, Julio. 1978. Clases, estado y nación en el Perú. Lima: Instituto de Estudios Peruanos.

Crowder, Michael. 1968. West Africa under Colonial Rule. London: Hutchinson.

Curtin, Philip. 1969. The Atlantic Slave Trade: A Census. Madison: University of Wisconsin Press.

D'Altroy, Terence N. 2002. The Incas. Oxford: Blackwell.

Denevan, William M. 1992. "Native American Populations in 1492: Recent Research and a Revised Hemispheric Estimate." Pp. xvii-xxix in The Native Population of the Americas, 2d ed., edited by William M. Denevan. Madison: University of Wisconsin Press.

Denoon, Donald. 1983. Settler Capitalism. Oxford: Clarendon.

Denoon, Donald, and Philippa Mein-Smith. 2000. A History of Australia, New Zealand, and the Pacific. Oxford: Blackwell.

de Silva, Chandra Richard. 1997. Sri Lanka: A History. New Delhi: Vikas.

Drèze, Jean, and Amartya Sen. 1989. Hunger and Public Action. Oxford: Oxford University Press.

Edwardes, Michael. 1967. British India, 1772-1947: A Survey of the Nature and Effects of Alien Rule. London: Sidgwick and Jackson.

Ekelund, Robert B., and Robert D. Tollison. 1981. Mercantilism as a Rent-Seeking Society: Economic Regulation in Historical Perspective. College Station: Texas A\&M University Press.

Emerson, Rupert. 1937. Malaysia: A Study of Direct and Indirect Rule. New York: Macmillan.

Engerman, Stanley L., and Kenneth L. Sokoloff. 2002. "Factor Endowments, Inequality, and Paths of Development among New World Economies." Economia 3:41-88.

Evans, Peter B. 1995. Embedded Autonomy: States and Industrial Transformation. Princeton, N.J.: Princeton University Press.

Fage, J. D. 2002. A History of Africa, 4th ed. New York: Routledge.

Ferguson, Niall. 2002. Empire: The Rise and Demise of the British World Order and the Lessons for Global Power. New York: Basic Books.

Ferleger, Louis. 1985. "Capital Goods and Southern Economic Development." Journal of Economic History 45:411-17.

Fieldhouse, D. K. 1966. The Colonial Empires: A Comparative Survey from the Eighteenth Century. London: Weidenfeld and Nicolson.

Filmer, Deon, and Lant Pritchett. 1999. "The Impact of Public Spending on Health: Does Money Matter?" Social Science and Medicine 49:1309-23.

Fisher, John. 1985. Commercial Relations between Spain and Spanish America in the Era of Free Trade, 1778-1796. Liverpool: Liverpool University Press. 


\section{Colonialism and Development}

Fisher, Michael. 1991. Indirect Rule in India: Residents and the Residency System. Dehli: Oxford University Press.

Florescano, Enrique. 1975. Haciendas, latifundios y plantaciones en América Latina. Mexico City: Siglo Veintiuno.

Frank, Andre Gunder. 1972. Lumpenbourgeoisie/Lumpendevelopment: Dependence, Class, and Politics in Latin America. New York: Monthly Review.

Galenson, David W. 1996. "The Settlement and Growth of the Colonies: Population, Labor, and Economic Development." Pp. 135-207 in The Cambridge Economic History of the United States, edited by Stanley L. Engerman and Robert E. Gallman. Cambridge: Cambridge University Press.

Goldsworthy, David. 1971. Colonial Issues in British Politics, 1945-1961: From 'Colonial Development' to 'Winds of Change.' Oxford: Clarendon.

Gopal, Ram. 1963. British Rule in India: An Assessment. New York: Asia.

Gorman, G. E., and J. J. Mills. 1994. Fiji. Denver: Clio.

Grier, Robin M. 1999. "Colonial Legacies and Economic Growth." Public Choice 98: 317-35.

Guardino, Peter, and Charles Walker. 1992. "State, Society, and Politics in Peru and Mexico in the Late Colonial and Early Republican Periods." Latin American Perspectives 19:10-43.

Haber, Stephen. 1991. "Industrial Concentration and the Capital Markets: A Comparative Study of Brazil, Mexico, and the United States, 1830-1930.” Journal of Economic History 51:559-80.

1997. "Financial Markets and Industrial Development: A Comparative Study of Government Regulation, Financial Innovation, and Industrial Structure in Brazil and Mexico, 1840-1930." Pp. 146-78 in How Latin America Fell Behind: Essays on the Economic Histories of Brazil and Mexico, 1800-1914, edited by Stephen Haber. Stanford, Calif.: Stanford University Press.

Halperín Donghi, Tulio. 1985. Reforma y disolución de los imperios ibéricos, 1750-1850. Madrid: Alianza Editorial.

- 1993. The Contemporary History of Latin America. Durham, N.C.: Duke University Press.

Hansen, Roger D. 1971. The Politics of Mexican Development. Baltimore: Johns Hopkins University Press.

Haring, C. H. 1947. The Spanish Empire in America. New York: Oxford University Press.

Harper, T. A. 1999. The End of Empire and the Making of Malaya. Cambridge: Cambridge University Press.

Hechter, Michael. 1975. Internal Colonialism: The Celtic Fringe in British National Development, 1536-1966. Berkeley: University of California Press.

Heckscher, Eli F. 1935. Mercantilism. 2 vols. London: George Allen \& Unwin.

Heller, Patrick. 1999. The Labor of Development: Workers and the Transformation of Capitalism in Kerala, India. Ithaca, N.Y.: Cornell University Press.

Herbst, Jeffrey. 2000. States and Power in Africa: Comparative Lessons in Authority and Control. Princeton, N.J.: Princeton University Press.

Heussler, Robert. 1981. British Rule in Malaya: The Malayan Civil Service and Its Predecessors, 1867-1942. Westport, Conn.: Greenwood.

Hoberman, Louisa Schell, and Susan Migden Socolow, eds. 1986. Cities and Society in Colonial Latin America. Albuquerque: University of New Mexico Press.

Horwitz, Morton. 1977. The Transformation of American Law, 1780-1860. Cambridge, Mass.: Harvard University Press.

Huff, W. G. 1994. The Economic Growth of Singapore: Trade and Development in the Twentieth Century. New York: Cambridge University Press.

Hurwitz, Samuel J., and Edith Hurwitz. 1971. Jamaica: A Historical Portrait. New York: Praeger. 


\section{American Journal of Sociology}

Ibrahim, H. A. 1985. "African Initiatives and Resistance in North-East Africa." Pp. 63-86 in General History Africa, vol. 7: Africa under Colonial Domination, 1880-1935, edited by A. Adu Boahen. Berkeley and Los Angeles: University of California Press.

Jacobsen, Nils, and Hans-Jürgen Puhle, eds. 1986. The Economies of Mexico and Peru during the Late Colonial Period, 1760-1810. Berlin: Colloquium Verlag.

Jeffries, Charles. 1962. Ceylon: The Path to Independence. London: Pall Mall.

Jomo K. S., ed. 1993. Industrializing Malaysia: Policy, Performance, Prospects. New York: Routledge.

July, Robert W. 1998. A History of the African People. 5th ed. Prospect Heights, Ill.: Waveland.

Kaniki, M. H. Y. 1985. "The Colonial Economy: The Former British Zones.” Pp. 382-419 in General History Africa, vol. 7: Africa under Colonial Domination, 1880-1935, edited by A. Adu Boahen. Berkeley and Los Angeles: University of California Press.

Kicza, John E. 1983. Colonial Entrepreneurs, Families and Business in Bourbon Mexico City. Albuquerque: University of New Mexico Press.

Knight, Alan. 2001. "Democratic and Revolutionary Traditions in Latin America." Bulletin of Latin American Research 20:147-86.

Knöbl, Wolfgang. 1998. Polizei und Herrschaft im Modernisierungsprozess: Staatsbildung und innere Sicherheit in Preussen, England und Amerika 1700-1914. Frankfurt am Main: Campus Verlag.

Kohli, Atul. 2004. State-Directed Development: Political Power and Industrialization in the Global Periphery. Cambridge: Cambridge University Press.

Kuczynski, Robert. 1939. Colonial Population. London: Oxford University Press.

- 1948. Demographic Survey of the British Colonial Empire. Vol. 1. New York: Oxford University Press.

1949. Demographic Survey of the British Colonial Empire. Vol. 2. New York: Oxford University Press.

1953. Demographic Survey of the British Colonial Empire. Vol. 3. New York: Oxford University Press.

Kulkarni, V. B. 1964. British Dominion in India and After. Bombay: Bharatiya Vidya Bhavan.

Kulke, Hermann, and Dietmar Rothermund. 1998. A History of India. New York: Routledge.

Kumar, Anand. 1989. State and Society in India: A Study of the State's AgendaMaking, 1917-1977. New Dehli: Radiant.

Kumar, Dharma. 1998. Colonialism, Property and the State. Delhi: Oxford University Press.

Laitin, David. 1986. Hegemony and Culture: Politics and Religious Change among the Yoruba. Chicago: University of Chicago Press.

Landes, David S. 1998. The Wealth and Poverty of Nations. New York: W.W. Norton.

Lang, James. 1975. Conquest and Commerce: Spain and England in the Americas. New York: Academic Press.

Lange, Matthew. 2003. "Embedding the Colonial State: A Comparative-Historical Analysis of State Building and Broad-Based Development in Mauritius." Social Science History 27:397-423.

_ 2004. "The British Colonial Lineages of Despotism and Development." Ph.D. dissertation. Brown University, Department of Sociology.

. 2005. "The Rule of Law and Development: A Weberian Framework of States and State-Society Relations." Pp. 48-65 in States and Development: Historical Antecedents of Stagnation and Advance, edited by Matthew Lange and Dietrich Rueschemeyer. New York: Palgrave/Macmillan. 


\section{Colonialism and Development}

La Porta, Rafael, Florencio Lopez-de-Silanes, Andrei Shleifer, and Robert W. Vishny. 1998. "Law and Finance." Journal of Political Economy 106:1113-55.

- 1999. "The Quality of Government." Journal of Economics, Law and Organization 15:222-79.

Larraz López, José. 1963. La época del mercantilismo en Castilla, 1500-1700. Madrid: Aguilar.

Lee, J. M. 1967. Colonial Development and Good Government: A Study of the Ideas Expressed by the British Official Classes in Planning Decolonization, 1939-1964. Oxford: Clarendon.

LePoer, Barbara Leitch, ed. 1991. Singapore: A Country Study. Washington, D.C.: Library of Congress.

Lewis, Gordon K. 1968. The Growth of the Modern West Indies. New York: Monthly Review.

Lockhart, James, and Stuart B. Schwartz. 1983. Early Latin America: A History of Colonial Spanish America and Brazil. Cambridge: Cambridge University Press.

Lynch, John. 1958. Spanish Colonial Administration, 1782-1810. New York: Greenwood.

MacLeod, Murdo J. 1984. "Aspects of the Internal Economy." Pp. 315-60 in The Cambridge History of Latin America, edited by Leslie Bethell. Cambridge: Cambridge University Press.

Mahoney, James. 2003. "Long-Run Development and the Legacy of Colonialism in Spanish America." American Journal of Sociology 109:50-106.

Mahoney, James, and Matthias vom Hau. 2003. "Indigenous People, Colonialism, and Social Development in Spanish America." Paper presented at the annual meeting of the American Sociological Association, Atlanta, August.

Mamdani, Mahmood. 1996. Citizen and Subject: Decentralized Despotism and the Legacy of Late Colonialism. Princeton, N.J.: Princeton University Press.

Mandle, Jay. 1974. "The Plantation States as a Sub-region of the Post-bellum South." Journal of Economic History 34:732-38.

Marshall, P. J. 1968. Problems of Empire: Britain and India 1757-1813. New York: Barnes \& Noble.

Marx, Anthony W. 1998. Making Race and Nation: A Comparison of the United States, South Africa, and Brazil. Cambridge: Cambridge University Press.

Masani, R. P. 1960. British in India. London: Oxford University Press.

McEvedy, Colin, and Richard Jones. 1978. Atlas of World Population History. New York: Facts on File.

McGuire, James W. 2001. "Social Policy and Mortality Decline in East Asia and Latin America." World Development 29:1673-97.

McKinley, P. Michael. 1985. Pre-revolutionary Caracas: Politics, Economy, and Society, 1777-1811. New York: Cambridge University Press.

Mendez, Juan, Guillermo O'Donnell, and Paul Pinheiro, eds. 1999. The (Un)Rule of Law and the Underprivileged in Latin America. Notre Dame, Ind.: University of Notre Dame Press.

Metcalf, Barbara D., and Thomas R. Metcalf. 2002. A Concise History of India. Cambridge: Cambridge University Press.

Meyer, David. 2000. Hong Kong as a Global Metropolis. New York: Cambridge University Press.

Migdal, Joel. 1988. Strong Societies and Weak States: State-Society Relations and State Capabilities in the Third World. Princeton, N.J.: Princeton University Press.

Miles, William. 1994. Hausaland Divided: Colonialism and Independence in Nigeria and Niger. Ithaca, N.Y.: Cornell University Press.

Mörner, Magnus. 1976. "Spanish Migration to the New World prior to 1810: A Report on the State of Research." Pp. 737-804 in First Images of America: The Impact of 


\section{American Journal of Sociology}

New World on the Old, edited by Fredi Chiapelli. Berkeley: University of California Press.

1985. The Andean Past: Land, Societies and Conflicts. New York: Columbia University Press.

Morrison, Godfrey. 1971. The Southern Sudan and Eritrea: Aspects of Wider African Problems. London: Minority Rights Group.

Newson, Linda A. 1976. Aboriginal and Spanish Colonial Trinidad: A Study in Cultural Contact. New York: Academic Press.

—. 1985. "Indian Population Patterns in Colonial Spanish America." Latin American Research Review 20:41-74.

Ngo, Tak-Wing, ed. 1999. Hong Kong's History: State and Society under Colonial Rule. New York: Routledge.

North, Douglass C. 1990. Institutions, Institutional Change, and Economic Performance. New York: Cambridge University Press.

North, Douglass C., and Robert P. Thomas. 1973. The Rise of the Western World: A New Economic History. Cambridge: Cambridge University Press.

Nyrop, Richard, Beryl Benderly, Ann Cort, Newton Parker, James Perlmutter, RinnSup Shinn, and Mary Shivanandan. 1971. Area Handbook for Ceylon. Washington, D.C.: Government Printing Office.

Oliver, Roland Anthony. 1999. The African Experience: From Olduvai Gorge to the 21st Century. Boulder: Westview.

Oliver, Roland Anthony, and Anthony Atmore. 2005. Africa since 1800. 5th ed. Cambridge: Cambridge University Press.

Pagden, Anthony. 1995. Lords of All the World: Ideologies of Empire in Spain, Britain and France, c. 1500-c. 1800. New Haven, Conn.: Yale University Press.

Palmer, David Scott. 1977. "The Politics of Authoritarianism in Spanish America." Pp. 377-412 in Authoritarianism and Corporatism in Latin America, edited by James M. Malloy. Pittsburgh: University of Pittsburgh Press.

1980. Peru: The Authoritarian Tradition. New York: Praeger.

Pérez, Louis A. 1988. Cuba: Between Reform and Revolution. Oxford: Oxford University Press.

Pike, Douglas. 1970. Australia: The Quiet Continent. Cambridge: Cambridge University Press.

Psacharopoulos, George, and Harry A. Patrinos. 1994. "Indigenous People and Poverty in Latin America." Finance and Development 31:41-43.

Ragin, Charles C. 2000. Fuzzy-Set Social Science. Chicago: University of Chicago.

Roberts, Elfred, Sum Ngai Ling, and Peter Bradshaw. 1992. Historical Dictionary of Hong Kong and Macau. Metuchen, N.J.: Scarecrow.

Robinson, James, and Kenneth Sokoloff. 2003. "Historical Roots of Inequality in Latin America and the Caribbean." Pp. 191-228 in Inequality in Latin America and the Caribbean: Breaking with History? edited by David de Ferranti et al. Washington, D.C.: World Bank.

Robinson, Ronald. 1972. "Non-European Foundations of European Imperialism: Sketch for a Theory of Collaboration." Pp. 117-40 in Studies in the Theory of Imperialism, edited by Roger Owen and Bob Sutcliffe. London: Longman.

Rock, David. 1987. Argentina, 1516-1987: From Spanish Colonization to Alfonsín. Berkeley and Los Angeles: University of California Press.

Rodney, Walter. 1982. How Europe Underdeveloped Africa. Revised ed. Washington, D.C.: Howard University Press.

Roemer, John E. 1982. "New Directions in the Marxist Theory of Exploitation and Class." Politics and Society 11:253-87.

Rostworowski, Maria. 1988. Historia del Tahuantinsuyu. Lima: Instituto de Estudios Peruanos.

Rueschemeyer, Dietrich, and Peter B. Evans. 1985. "The State and Economic 


\section{Colonialism and Development}

Transformation: Toward an Analysis of the Conditions Underlying Effective Intervention." Pp. 44-77 in Bringing the State Back In, edited by Peter B. Evans, Dietrich Rueschemeyer, and Theda Skocpol. Cambridge: Cambridge University Press.

Ryan, N. J. 1976. A History of Malaysia and Singapore. New York: Oxford University Press.

Safford, Frank. 1985. "Politics, Ideology and Society in Post-independence Spanish America." Pp. 347-422 in The Cambridge History of Latin America, vol. 3: From Independence to $c$. 1870. Cambridge: Cambridge University Press.

Sánchez-Albornoz, Nicolás. 1974. The Population of Latin America: A History. Berkeley: University of California Press.

Sanders, Elizabeth. 1999. Roots of Reform: Farmers, Workers, and the American State, 1877-1917. Chicago: University of Chicago Press.

Smith, Adam. (1776) 2000. The Wealth of Nations. New York: Modern Library.

Smith, Martin. 1999. Burma: Insurgency and the Politics of Ethnicity. New York: Zed Books.

Smith, Michael E. 1996. The Aztecs. Oxford: Blackwell.

Socolow, Susan Migden. 1996. "Introduction to the Rural Past." Pp. 3-18 in The Countryside in Colonial Latin America, edited by Louisa Schell Hoberman and Susan Migden Socolow. Albuquerque: University of New Mexico Press.

Solberg, Carl E. 1987. The Prairies and the Pampas: Agrarian Policy in Canada and Argentina, 1880-1930. Stanford, Calif.: Stanford University Press.

Spalding, Karen. 1970. "Social Climbers: Changing Patterns of Mobility among Indians of Colonial Peru." Hispanic American Historical Review 50:645-64.

Spillman, Lyn. 1996. "'Neither the Same Nation nor Different Nations': Constitutional Conventions in the United States and Australia." Comparative Studies in Society and History 38:149-81.

Steckel, Richard H., and Jerome C. Rose. 2002. "Patterns of Health in the Western Hemisphere." Pp. 563-79 in The Backbone of History: Health and Nutrition in the Western Hemisphere, edited by Richard H. Steckel and Jerome C. Rose. Cambridge: Cambridge University Press.

Stern, Steve J. 1993. Peru's Indian Peoples and the Challenge of Spanish Conquest: Hamanga to 1640. Madison: University of Wisconsin Press.

Stokes, Eric. 1973. "The First Century of British Colonial Rule in India: Social Revolution or Social Stagnation?" Past and Present 58:136-60.

Stoler, Ann, and Frederick Cooper. 1997. "Between Metropole and Colony: Rethinking a Research Agenda." Pp. 1-58 in Tensions of Empire: Colonial Cultures in a Bourgeois World, edited by Frederick Cooper and Ann Stoler. Berkeley and Los Angeles: University of California Press.

Townsend, Richard F. 2001. The Aztecs. New York: Thames \& Hudson

United Nations. 2002. Human Development Report. New York: Oxford University Press.

Vail, LeRoy, ed. 1989. The Creation of Tribalism in Southern Africa. Berkeley and Los Angeles: University of California Press.

Vicens Vives, Jaime. 1969. An Economic History of Spain. Princeton, N.J.: Princeton University Press.

Walker, Geoffrey J. 1979. Spanish Politics and Imperial Trade, 1700-1789. Bloomington: Indiana University Press.

Wallerstein, Immanuel. 1974. "The Rise and Future Demise of the World Capitalist System: Concepts for Comparative Analysis." Comparative Studies in Society and History 16:387-415.

Weber, Max. 1978. Economy and Society: An Outline of Interpretive Sociology, edited by Guenther Ross and Claus Wittich. Berkeley: University of California Press. 


\section{American Journal of Sociology}

Whigham, Thomas. 1991. The Politics of River Trade: Tradition and Development in the Upper Plata, 1780-1870. Albuquerque: University of New Mexico Press.

Wolf, Eric R. 1982. Europe and the People Without History. Berkeley and Los Angeles: University of California Press.

Wolff, Richard D. 1974. The Economics of Colonialism: Britain and Kenya, 1870-1930. New Haven, Conn.: Yale University Press.

Woodward, Peter. 1990. Sudan, 1898-1989: The Unstable State. Boulder, Colo.: Lynne Rienner.

Wright, Erik Olin. 1997. Class Counts: Comparative Studies in Class Analysis. Cambridge: Cambridge University Press.

Wrigley, Christopher. 1996. Kingship and State: The Buganda Dynasty. New York: Cambridge University Press.

Young, Allen. 1958. The Approaches of Local Self-Government in British Guiana. London: Longmans, Green.

Young, Crawford. 1994. The African Colonial State in Comparative Perspective. New Haven, Conn.: Yale University Press.

Zawawi Ibrahim. 1998. The Malay Labourer: By the Window of Capitalism. Singapore: Stamford.

Zulawski, Ann. 1990. "Frontier Workers and Social Change." Pp. 112-27 in Migration in Colonial Spanish America, edited by David J. Robinson. Cambridge: Cambridge University Press. 